\title{
Aktualisasi Konsep Kafa'ah Dalam Membangun Keharmonisan Rumah Tangga*
}

\author{
(ACTUALIZATION OF THE CONCEPT KAFA'AH IN BUILDING \\ HARMONIOUS HOUSEHOLD)
}

\author{
Syarifah Gustiawati \& Novia Lestari \\ FAI Universitas Ibn Khaldun (UIKA) Bogor \\ Jl. KH. Sholeh Iskandar Bogor \\ E-mail: liefah@gmail.com
}

\begin{abstract}
Marriage is sunnatullah general and applies to all His creatures, whether in humans, animals and plants, and a way chosen by God as a way for His creatures to breed and preserve his life. Marriage will play after each pair is ready to do a positive role in realizing the goal of marriage itself. Included in terms $k a f a^{\prime} a h$. The husband and wife should be able to actualize in building domestic harmony, in order to reach a destination wedding is sakinah, mawaddah wa Rahmah.
\end{abstract}

Keywords: Kafa'ah, Household, Marriage

\begin{abstract}
Abstrak: Pernikahan merupakan sunnatullah yang umum dan berlaku pada semua makhluk-Nya, baik pada manusia, hewan maupun tumbuh-tumbuhan, dan suatu cara yang dipilih oleh Allah SWT sebagai jalan bagi makhluk-Nya untuk berkembang biak, dan melestarikan hidupnya. Pernikahan akan berperan setelah masing-masing pasangan siap melakukan peranannya yang positif dalam mewujudkan tujuan dari pernikahan itu sendiri. Termasuk dalam hal kafa'ah. Pasangan suami istri harus mampu mengaktualisasikannya dalam membangun keharmonisan rumah tangga, sehingga tercapai tujuan pernikahan yaitu sakinah, mawaddah wa rahmah.
\end{abstract}

Kata Kunci: Kafa'ah, Rumah Tangga, Pernikahan

${ }^{*}$ Diterima tanggal naskah diterima: 05 April 2016, direvisi: 10 Mei 2016, disetujui untuk terbit: 22 Mei 2016. 


\section{Pendahuluan}

Pernikahan memang merupakan persoalan untuk senantiasa dibahas dan dibicarakan, mengingat pernikahan merupakan pilar utama dari pintu gerbang terbentuknya sebuah keluarga yang darinya akan melahirkan tatanan kehidupan yang baik dimasa yang akan datang, dengan lahirnya generasigenerasi yang tangguh di dalam memperjuangkan agama Allah.

Islam mengatur manusia dalam hidup berjodoh-jodohan itu melalui jenjang perkawinan yang ketentuannya dirumuskan dalam wujud aturanaturan yang disebut hukum perkawinan dalam Islam. Hukum Islam juga ditetapkan untuk kesejahteraan umat, baik secara perorangan maupun secara bermasyarakat, baik untuk hidup di dunia maupun di akhirat. Kesejahteraan masyarakat akan tercapai dengan terciptanya kesejahteraan yang sejahtera dalam perkawinan, karena keluarga merupakan lembaga terkecil dalam masyarakat sehingga kesejahteraan masyarakat sangat tergantung kepada kesejahteraan keluarga. Demikian pula kesejahteraan perorangan sangat dipengaruhi oleh kesejahteraan hidup keluarga. ${ }^{1}$

Islam memandang pernikahan sebagai mitsaqon gholidzhon, yaitu sebuah perjanjian yang kokoh, terdapat dalam Q.S. An-Nisa : 21,

Bagaimana kamu akan mengambilnya kembali, padahal sebagian kamu telah bergaul (bercampur) dengan yang lain sebagai suamiisteri. dan mereka (isteri-isterimu) telah mengambil dari kamu perjanjian yang kuat.

Ungkapan akad yang sangat kuat atau mitsaqan ghalizhan merupakan penjelasan dari ungkapan "ikatan lahir bathin" yang terdapat dalam rumusan UU yang mengandung arti bahwa akad perkawinan itu bukanlah semata perjanjian yang bersifat keperdataan. Hal ini lebih menjelaskan bahwa perkawinan bagi umat Islam merupakan peristiwa agama dan oleh karena itu orang yang melaksanakannya telah melakukan perbuatan ibadah.

Di samping perkawinan itu merupakan suatu perbuatan ibadah, perempuan yang sudah menjadi istri itu merupakan amanah Allah yang harus dijaga dan diperlakukan dengan baik. Ini pun merupakan salah satu akibat dari ketidaktahuan seseorang atas konsep pernikahan dalam Islam yang memposisikan istri sebagai "pakaian suami" dan suami sebagai "pakaian

\footnotetext{
${ }^{1}$ Abd. Rahman Ghazaly, Fiqh Munakahat, (Bogor: Kencana, 2003), h. 13.
} 
istri." Berarti secara hukum posisi suami-istri harus setara, sejajar, atau semitra. $^{2}$

Menikah itu keputusan besar dan istimewa dalam hidup, lebih besar dari keputusan apapun, karena merupakan kerja yang membutuhkan energi besar dengan tantangan besar pula. Maka dari itu pernikahan tidak boleh dilakukan secara asal-asalan. Sebab, ini terkait dengan masa depan yang panjang bahkan sampai di akhirat. Dikarenakan keputusan yang besar, sebaiknya harus dipikirkan dan direncanakan sematang mungkin dan sejelas mungkin, karena menikah itu fitrah dan naluri manusia untuk membangun rumah tangga yang bahagia. ${ }^{3}$

Islam mendorong untuk membentuk keluarga, mengajak manusia untuk hidup dalam naungan keluarga, karena keluarga seperti gambaran kecil dalam kehidupan stabil yang menjadi pemenuhan keinginan manusia, tanpa menghilangkan kebutuhannya. Keluarga merupakan tempat fitrah yang sesuai dengan keinginan Allah, bagi kehidupan manusia sejak keberadaan khalifah, Allah berfirman dalam Qur'an surat Ar-Ra'd: 38, yang berbunyi:

Dan sesungguhnya Kami telah mengutus beberapa Rasul sebelum kamu dan Kami memberikan kepada mereka isteri-isteri dan keturunan, dan tidak ada hak bagi seorang Rasul mendatangkan sesuatu ayat (mukjizat) melainkan dengan izin Allah, bagi tiap-tiap masa ada kitab (yang tertentu).

Kehidupan manusia secara individu berada dalam perputaran kehidupan dengan berbagai arah yang menyatu dengannya. Karena sesungguhnya fitrah kebutuhan manusia mengajak untuk menuju keluarga bahagia, sehingga mencapai kerindangan dalam tabiat kehidupan. Bahwasanya tidak ada kehidupan yang dihadapi dengan kesungguhan oleh pribadi yang kecil, dikarenakan membutuhkan unsur-unsur kekuatan, saling tolong menolong dalam menanggung beban, serta menghadapi kesulitan dari segenap kebutuhan aturan keluarga. ${ }^{4}$

Salah satu problematika yang menarik untuk senantiasa dibahas ketika membicarakan masalah pernikahan adalah konsep kafa'ah (kesetaraan). Konsep kafa'ah dalam perkawinan sangat berpengaruh dalam membentuk

2 Amir Syarifuddin, Hukum Perkawinan Islam di Indonesia, Jakarta: Kencana, 2007, h. 40.

${ }^{3}$ Muhammad Yasir, Ya Allah Bahagiakan Keluarga Kami, Jakarta: Pustaka Al-Kautsar, 2013, h. 12.

${ }^{4}$ Ali Yusuf As-Subki, Figh Keluarga, Jakarta: Amzah, 2010, h. 23. 
keluarga harmonis, sejauh mana kafa'ah dalam perkawinan merupakan faktor yang dapat mendorong terciptanya kebahagiaan suami istri dan lebih menjamin keselamatan perempuan dari kegagalan atau kegoncangan rumah tangga.

Tekanan dalam hal kafa'ah adalah keseimbangan, keharmonisan dan keserasian, terutama dalam hal agama, yaitu akhlak dan ibadah. Sebab kalau kafa'ah diartikan dengan persamaan dalam hal harta atau kebangsawanan maka akan berarti terbentuknya kasta, sedang dalam Islam tidak dibenarkan adanya kasta, karena manusia di sisi Allah SWT adalah sama hanya ketakwaannyalah yang membedakannya. ${ }^{5}$ Setiap orang muslim meyakini tentang kedudukan akhlak dalam kehidupan individu, berkeluarga, bermasyarakat, dan bernegara. Sehingga terdapat bagian dari akhlak dan adab yang harus ada pada seorang laki-laki dan perempuan yang hendak menikah.

Pernikahan antara laki-laki dan perempuan memiliki konsekuensi sosial yang sangat besar. Oleh karena itu, sepasang calon suami-istri harus meletakkan pondasi yang kukuh dan kuat agar pernikahannya berhasil dan dapat terus melaju, dan tidak ada pondasi yang lebih kuat dibanding keimanan. ${ }^{6}$ Agama telah menunjukkan bahwa dalam setiap permasalahan harus dipertimbangkan konsekuensinya sehingga kehidupan keluarga akan terus berlangsung sampai akhir hayat termasuk dalam hal perkawinan.

Dari keterangan tersebut, jelaslah bahwa prinsip memilih pasangan yang dikehendaki Islam ialah ketekunan beragama dan akhlak yang luhur, bahwa kemegahan harta, nasab, kecantikan itu sebagai penyempurna, karena kelebihan antara satu dengan yang lain hanyalah didasarkan ketakwaannya kepada Allah, amalnya yang shaleh dan kemauannya untuk berpegang teguh pada agama Allah dan menjauhi kehendak nafsu dan syahwat. ${ }^{7}$

Maka dari itu tidak diragukan lagi bahwa keseimbangan keberadaan antara suami dan istri akan lebih menjamin keharmonisan dan kesuksesan hidup serta dapat menghindarkan diri dari keretakan dan kehancuran keluarga. Namun, secara umum sudut pandang yang membenarkan adanya stratifikasi di bidang perkawinan tetap memprioritaskan aspek keagamaan, artinya dalam soal agama itu sangat penting untuk dijadikan sebagai tolak

\footnotetext{
${ }^{5}$ Slamet Abidin, Aminuddin, Fiqih Munakahat, h. 50.

${ }^{6}$ Syaikh Mutawalli Asy-Sya'rawi, Fikih Perempuan, Jakarta: Amzah, 2003, h. 176.

${ }^{7}$ Muhammad Fuad, Fiqih Wanita, Jombang : Lintas Media, 2007, h. 396.
} 
ukur dalam menentukan suatu keputusan yang berkaitan dengan perkawinan.

Ditinjau dari alasannya, mengenai pokok agama seperti Islam dan bukan Islam maupun kesempurnaannya, misalnya orang yang baik (taat) tidak sederajat dengan orang yang jahat atau orang yang tidak taat. ${ }^{8}$ Larangan demikian menunjukan adanya idealitas kesetaraan di bidang agama yang tidak boleh diabaikan.

Orang Islam yang menikah dengan orang non muslim dianggap bukan sekufu" yakni tidak sepadan seperti yang ada dalam Alquran Surat AlBaqarah: 221, yang berbunyi:

Dan janganlah kamu menikahi wanita-wanita musyrik, sebelum mereka beriman. Sesungguhnya wanita budak yang mukmin lebih baik dari wanita musyrik, walaupun dia menarik hatimu, dan janganlah kamu menikahkan orang-orang musyrik (dengan wanita-wanita mukmin) sebelum mereka beriman. Sesungguhnya budak yang mukmin lebih baik dari orang musyrik, walaupun dia menarik hatimu mereka mengajak ke neraka, sedang Allah mengajak ke surga dan ampunan dengan izin-Nya, dan Allah menerangkan ayat-ayat-Nya (perintah-perintah-Nya) kepada manusia supaya mereka mengambil pelajaran.

Kafa'ah juga dapat mempersiapkan pribadi seorang laki-laki maupun wanita untuk lebih matang dan bertanggung jawab dalam memasuki dan menjalankan kehidupan berkeluarga (perkawinan). Dan ini tinggal bagaimana masing-masing pihak dapat memposisikan kafa'ah sebagai ajaran luhur yang melindungi hak-hak asasinya dan hak asasi pihak lainnya. Memang tercapainya tujuan pernikahan tidak mutlak ditentukan oleh faktor kesepadanan semata, tetapi hal tersebut bisa menjadi penunjang yang utama.

Faktor-faktor yang menjadi kriteria lain diluar sekufu dalam agama yaitu sikap hidup yang lurus dan sopan, bukan karena keturunan, kecantikan, kekayaan, dan sebagainya. Seorang laki-laki yang shaleh walaupun berasal dari keturunan rendah berhak menikah dengan perempuan yang berderajat tinggi, laki-laki yang mempunyai kebesaran apapun berhak menikah dengan perempuan yang memiliki derajat dan kemashuran yang tinggi. Begitu pula laki-laki yang fakir sekalipun, berhak dan boleh menikah dengan perempuan

${ }^{8}$ Sulaiman Rasjid, Figh Islam, Bandung: Sinar Baru Algensindo, 2012, h. 391. 
yang kaya raya, asalkan laki-laki itu muslim dan dapat menjauhkan diri dari meminta-minta. ${ }^{9}$

Faktor-faktor tersebut merupakan syarat yang ideal tetapi sebagai manusia biasa tidak selamanya sempurna pasti akan ada kekurangannya, sehingga jarang didapati seorang calon suami atau calon istri yang memiliki faktor-faktor tersebut secara menyeluruh. Apabila faktor-faktor tersebut tidak dimiliki dan didapati seluruhnya, maka yang harus diutamakan adalah faktor agama. Karena dalam pandangan Islam semua manusia sama, tidak ada perbedaan antara kaya dan miskin, putih dan hitam maupun yang kuat dan yang lemah.

Dilihat dari tujuan pernikahan tersebut, kafa'ah dalam pernikahan dapat mendukung tercapainya tujuan pernikahan. Latar belakang diterapkannya konsep kafa'ah dalam pernikahan bertujuan agar tercapainya rumah tangga yang harmonis dan apabila terdapat kerjasama antara suami dan istri dapat berjalan dengan baik sehingga tercipta suasana keluarga yang damai, aman, dan sejahtera. ${ }^{10}$

\section{Kerangka Teoritis Tentang Kafa'ah Dalam Perkawinan}

Kafa'ah sebanding, setaraf dan sesuai). ${ }^{11}$ Yang dimaksud dengan kafa'ah atau $k u f u '$ dalam perkawinan, menurut istilah hukum Islam yaitu keseimbangan dan keserasian antara calon suami dan calon isteri sehingga masing-masing calon tidak merasa berat untuk melangsungkan perkawinan. ${ }^{12}$

Kesetaraan perlu dimiliki oleh calon suami dan istri, agar dihasilkan keserasian hubungan suami istri secara mantap dalam menghindari masalahmasalah tertentu. Istilah $k a f a$ 'ah dibahas oleh ulama fiqh dalam masalah perkawinan pada saat membicarakan jodoh seorang wanita. Dilihat dari satu segi, persoalan $k a f a ' a h$ memang dirasa penting, agar terjadi keserasian dalam kehidupan suami istri dalam membina rumah tangga. ${ }^{13}$

${ }^{9}$ Slamet Abidin, Aminuddin, Fiqih Munakahat, Bandung: CVPustakasetia, 1999, h. 52.

${ }^{10}$ Muhammad Ishar Helmi, “Pengadilan Khusus KDRT; Implementasi Gagasan Sistem Peradilan Pidana Terpadu Penanganan Kasus-Kasus Kekerasan Terhadap Perempuan (SPPTPKKTP)", Jurnal Cita Hukum [Online], Volume 2 Number 2 (1 Desember 2014), h.319.

${ }^{11}$ M. Ali Hasan, Pedoman Hidup Berumah Tangga dalam Islam, Jakarta: Siraja, 2006, h. 33.

${ }^{12}$ Abdul Rahman Ghazali, Fikih Munakahat, Bogor: Kencana, 2003, h. 96.

${ }^{13}$ M. Ali Hasan, Pedoman Hidup Berumah Tangga dalam Islam, h. 33. 
Kata $k u f u^{\prime}$ atau kafa'ah dalam perkawinan mengandung arti bahwa perempuan harus sama atau setara dengan laki-laki. Sifat kafa'ah mengandung arti sifat yang terdapat pada perempuan yang dalam perkawinan sifat tersebut diperhitungkan harus ada pada laki-laki yang menikahinya.

Kafa'ah itu disyariatkan atau diatur dalam perkawinan Islam, namun karena dalil yang mengaturnya tidak ada yang jelas dan spesifik baik dalam Alquran maupun dalam hadits Nabi, maka kafa'ah menjadi pembicaraan dikalangan ulama, baik mengenai kedudukannya dalam perkawinan maupun kriteria apa yang digunakan dalam penentuan kafa'ah tersebut. ${ }^{14}$

Suami isteri seimbang kedudukannya, maksudnya tiap-tiap pekerjaan yang diperbuat oleh istri untuk suami, begitupula pekerjaan suami untuk istrinya, maka kedua-duanya bersamaan dan berseimbangan tentang hak-hak dan kewajiban, sebagaimana keduanya bersamaan tentang jasmani dan rohani, sama-sama berperasaan, berpikiran, berkemauan atau dengan perkataan lain sama-sama manusia yang sempurna. ${ }^{15}$

Kelanggengan pernikahan dimulai sejak awal mula usaha menuju pernikahan dan sangat dipengaruhi oleh penentuan pilihan, siapa yang akan dijadikan pasangan hidup, disinilah Islam memberikan tuntutan agar suatu pernikahan disandarkan kepada pilihan yang terbaik serta disandarkan kepada asas yang kuat yang akan mampu mencapai kesucian, kejernihan dan keserasian, juga disandarkan kepada kebahagiaan dan ketentraman. ${ }^{16}$

Dari penjelasan di atas dapat dipahami bahwa istilah kafa'ah sangat terkait erat dengan masalah perkawinan, dimana dalam memilih pasangan terdapat kriteria-kriteria didalamnya untuk menjalani suatu perkawinan, yakni adanya kesetaraan atau kesesuaian antara calon suami dan isteri dalam beberapa aspek tertentu yang dapat menghindarkan terjadinya krisis dalam rumah tangga sehingga dapat menunjang tercapainya keluarga yang harmonis.

Kafa'ah adalah bukan dari syari'at Islam, artinya Islam tidak menetapkan bahwa seorang laki-laki hanya boleh menikah dengan perempuan yang sama kedudukannya, seorang miskin tidak boleh menikah

${ }^{14}$ Amir Syarifuddin, Hukum Perkawinan Islam di Indonesia, Jakarta: Kencana Prenada Media Group, 2006, h. 140.

${ }^{15}$ Mahmud Junus, Hukum Perkawinan dalam Islam, Jakarta: Pustaka Mahmudiah, 1964, h. 95.

${ }^{16}$ Yahya Abdurrahman, Risalah Khitbah, Bogor: Al-Azhar Press, 2013, Cet. III, h. 82. 
dengan orang kaya, orang Arab tidak boleh menikah dengan orang Indonesia, pedagang tidak boleh menikah dengan karyawan, Islam tidak mengajarkan demikian. Islam adalah agama fitrah yang condong kepada kebenaran, Islam tidak membuat aturan tentang kafa'ah tetapi manusialah yang menetapkannya, karena itulah mereka berbeda pendapat tentang hukum kafa'ah dan pelaksanaannya. ${ }^{17}$

Ibnu Hazm mengatakan "orang Islam manapun asal bukan pezina berhak menikahi wanita muslimat mana saja, selagi bukan pezina. Ditambahkan pula, orang Islam semua adalah bersaudara, orang Islam yang fasik sampai batas tertentu, yakni yang tidak sampai berzina adalah cocok untuk wanita muslimat yang fasik pula asal bukan pezina".

Segolongan Ulama berpendapat bahwa $k u f u$ ' itu patut diperhatikan, hanya yang menjadi ukuran ialah keteguhan beragama dan akhlak, bukan nasab, usaha, kekayaan ataupun sesuatu yang lain. Jadi, bagi laki-laki yang shalih, sekalipun bukan dari keturunan yang terpandang boleh menikah dengan wanita manapun, dan laki-laki dengan pekerjaan yang dipandang rendah boleh beristeri yang mempunyai kedudukan tinggi. Laki-laki miskin pun boleh menikah dengan wanita kaya raya, asalkan muslim dan pandai memelihara diri dari perbuatan yang keji dan memenuhi kriteria yang diminta oleh wali pemegang akad, serta pihak calon isteri pun menerima perkawinan tersebut dengan senang hati. Akan tetapi, apabila laki-laki tidak teguh dalam menunaikan agamanya, maka tidak patut menikahi wanita yang shalih, dan apabila dilangsungkan juga perkawinan yang tidak seimbang, maka wanita berhak menuntut dibatalkannya akad (fasakh), yakni wanita perawan yang oleh ayahnya dipaksa menikah dengan laki-laki fasik.

Ibnu Rusyd berkata dalam kitab Bidayat Al-Mujtahid "Tidak ada perbedaan pendapat dalam madzhab Maliki, bahwa perawan yang dipaksa ayahnya untuk menikah dengan laki-laki peminum khamar atau orang fasik mana saja, maka berhak menolak". ${ }^{18}$

Menurut jumhur Ulama, kafa'ah yang dituntut hanya dalam sifat istiqamah dan kesalehan, nasab, kebebasan, pekerjaan dan harta. Maksudnya supaya dalam pernikahan semua faktor kestabilan dan keharmonisan rumah tangga terpenuhi, serta keluarga terhindar dari sebab-sebab perpecahan, bahaya dan kesulitan, karena pernikahan dilaksanakan untuk mewujudkan

\footnotetext{
17 H.S.A. Al-Hamdani, Risalah Nikah, Jakarta: Pustaka Amani, 1989, h. 98.

${ }^{18}$ Muhammad Fuad, Fiqh wanita, Jombang: Lintas Media, 2007, h. 394.
} 
pergaulan, pertemanan, kasih sayang, dan kekerabatan. Semua itu tidak mungkin terwujud kecuali diantara orang-orang yang sekufu'.19

Dalam hal kedudukannya dalam perkawinan terdapat perbedaan pendapat dikalangan para ulama. Jumhur ulama termasuk Malikiyah, Syafi'iyah dan Ahlu Ra'yi (Hanafiyah) dan satu riwayat dari Imam Ahmad berpendapat bahwa kafa'ah itu tidak termasuk syarat dalam pernikahan dalam arti kafa'ah itu hanya semata keutamaan, dan sah pernikahan antara orang yang tidak sekufu. Sebagian ulama termasuk satu riwayat dari Ahmad mengatakan bahwa kafa'ah itu termasuk syarat sahnya perkawinan, artinya tidak sah perkawinan antara laki-laki dan perempuan yang tidak sekufu. ${ }^{20}$ Dalam kriteria yang digunakan untuk menentukan kafa'ah, ulama berbeda pendapat yang secara lengkap diuraikan oleh Al-Jaziriy sebagai berikut :

Menurut ulama Hanafiyah yang menjadi dasar kafa'ah adalah: a). Nasab, yaitu keturunan atau kebangsaan; b). Islam, yaitu dalam silsilah kerabatnya banyak yang beragama Islam; c). Hirfah, yaitu profesi dalam kehidupan; d). Kemerdekaan dirinya; e). Diyanah atau tingkat kualitas keberagamannya dalam Islam; f). Kekayaan.

Menurut ulama Malikiyah yang menjadi kriteria kafa'ah hanyalah diyanah atau kualitas keberagamaan dan bebas dari cacat fisik. Sedang menurut ulama Syafi'iyah yang menjadi kriteria kafa'ah adalah; a). Kebangsaan atau nasab, b). Kualitas keberagamaan, c). Kemerdekaan diri, dan d). Usaha atau profesi.

Menurut ulama Hanabilah yang menjadi kriteria kafa'ah adalah; a). Kualitas keberagamaan, b). Usaha atau profesi, c). Kekayaan, d). Kemerdekaan diri, dan e). Kebangsaan.

Para Ulama sepakat menempatkan dien atau diyanah yang berarti tingkat ketaatan beragama sebagai kriteria kafa'ah bahkan menurut ulama Malikiyah hanya inilah satu-satunya yang dapat dijadikan kriteria kafa'ah. ${ }^{21}$ Kesepakatan tersebut didasarkan kepada firman Allah yang disebutkan di atas juga dalam Qur'an surat As-Sajdah : 18, yaitu: Apakah orang-orang beriman itu sama dengan orang-orang yang fasik? mereka tidak sama.

${ }^{19}$ Syaikh Mahmud Al-Mashri, Bekal Pernikahan, Jakarta: Qisthi Press, 2010, h. 268.

${ }^{20}$ Amir Syarifuddin, Hukum Perkaiwnan Islam di Indonesia, Jakarta: Kencana Prenada Media Group, 2006, h. 141.

${ }^{21}$ Amir Syarifuddin, Hukum Perkaiwnan Islam di Indonesia, h. 142. 
Persamaan akhlak dan agama menurut madzhab Maliki lebih dekat dan lebih tepat dengan ajaran Islam. Tetapi kenyataannya ahli fikih dari kalangan Hanafi, Syafi'i serta Hambali memasukkan ukuran lain dalam kafa'ah, tidak seperti yang digariskan oleh Malikiyah.

Perinciannya yang pertama dalam hal nasab, orang Arab adalah sekufu' bagi orang Arab, Quraisy adalah sekufu' bagi Quraisy lainnya. Orang Arab biasa tidak sekufu' dengan orang-orang Quraisy. Kriteria yang kedua yaitu Islam, kufu' berdasarkan keIslaman pada dasarnya digunakan bagi selain orang Arab. Sedangkan orang Arab kafa'ahnya tidak diukur dengan ke Islamannya sebab mereka bangga dengan nasab atau keturunan. Sedangkan orang-orang selain Arab mereka akan bangga dengan keIslaman leluhur.

Apabila seorang perempuan mempunyai ayah dan kakek yang Islam maka tidak sekufu' dengan orang yang mempunyai ayah dan kakek yang bukan Islam. Sebab perceraian dapat dituntut oleh ayah atau kakek, hak menuntut cerai tidak akan berpindah kepada selain ayah dan kakek.

Abu Yusuf berpendapat bahwa "seseorang yang mempunyai ayah muslim sekufu dengan perempuan yang mempunyai leluhur muslim, karena mereka cukup dikenal dengan menyebutkan nama ayahnya". ${ }^{22}$

Ketiga yaitu kriteria pekerjaan, apabila seorang perempuan berasal dari kalangan orang-orang yang mempunyai kerja tetap dan terhormat tidak dianggap sekufu dengan seorang yang rendah penghasilannya. Ukuran tinggi rendahnya usaha adalah menurut adat, adakalanya pekerjaan disuatu daerah dan pada suatu masa dipandang terhormat tetapi ditempat dan dilain waktu mungkin dipandang hina.

Keempat kriteria kekayaan, dalam hal kekayaan Ulama Syafi'iyah berbeda-beda dalam menetapkan kafa'ah. Sebagian menganggapnya sebagai ukuran $k u f u^{\prime}$, misalnya seorang miskin dianggap tidak sekufu' dengan orang kaya. Dengan alasan, bahwa nafkah orang miskin berbeda dengan nafkahnya orang kaya. Ada pula ulama Syafi'iyah yang tidak menganggap kekayaan sebagai ukuran kafa'ah karena hakekatnya kekayaan itu yang pokok adalah makan dan perbekalan.

Ulama Hanafiyah menguatkan pendapat tentang kekayaan sebagai ukuran kafa'ah, mereka mengatakan "Yang dianggap sekufu yaitu seorang laki-

\footnotetext{
${ }^{22}$ H.S.A. Alhamdani, Risalah Nikah, Jakarta: Pustaka Amani, 1989, h. 101.
} 
laki yang sanggup membayar maskawin dan uang belanja, sehingga apabila tidak sanggup membayar maskawin dan nafkah dianggap tidak sekufu'.

Menurut Abu Yusuf sahabat Abu Hanifah bahwa ukuran kafa'ah adalah "kesanggupan membayar atau memberi nafkah bukan membayar maskawin, karena ukuran yang mudah dilakukan seseorang dan kemampuannya untuk memberi nafkah tidak dapat dilhat dari keadaan ayahnya".

Imam Ahmad bin Hambal pun menganggap kekayaan sebagai ukuran kafa'ah, beliau berkata "Orang miskin akan menyusahkan istrinya dalam memberi belanja, karena orang disebut fakir dilihat dari sedikit atau banyaknya kekayaan yang dimiliki. Seperti terhormatnya seseorang karena lebih terpandang dan terhormat nenek moyangnya. ${ }^{23}$

Diantara ulama yang sepakat kebanyakannya tidak menempatkan $k a f a ' a h$ sebagai syarat, kafa'ah dalam hal ini hanyalah keutamaan. Dalam mengambil menantu umpamanya bila berkompetisi antara yang taat dengan yang biasa-biasa saja maka harus didahulukan yang taat. Bila seorang ayah menolak mengawinkan anak perempuannya dengan alasan calon yang diajukan itu tidak memenuhi kriteria kafa'ah dia tidak boleh dinyatakan sebagai wali adhal atau enggan yang menyebabkan kewalian pindah kepada wali hakim. Demikian pula anak perempuan dapat menolak kehendak walinya yang akan mengawinkannya dengan laki-laki yang tidak memenuhi kriteria kafa'ah tersebut.

Kafa'ah yang menjadi perbincangan hampir disemua kitab fiqh, sama sekali tidak disinggung oleh UU perkawinan dan hanya disinggung sekilas dalam KHI, yaitu pada pasal 61 dalam membicarakan pencegahan perkawinan, dan yang diakui sebagai kriteria kafa'ah itu adalah yang telah menjadi kesepakatan ulama, yaitu kualitas keberagamaan. ${ }^{24}$ Pasal 61 dinyatakan: "Tidak sekufu, tidak dapat dijadikan alasan untuk mencegah perkawinan, kecuali tidak sekufu karena perbedaan agama atau ikhtilafu aldien". ${ }^{25}$ Karena itu, hendaknya seorang laki-laki atau wanita memilih

${ }^{23}$ H.S.A. Alhamdani, Risalah Nikah, h. 103.

${ }^{24}$ Amir Syarifuddin, Hukum Perkawinan Islam di Indonesia, Jakarta : Kencana Prenada Media Group, 2011, h. 143-144.

${ }^{25}$ Undang-Undang R.I. Nomor 1 Tahun 1974, Perkawinan dan Kompilasi Hukum Islam, Bandung: Citra Umbara, 2012, h. 340. 
pasangan hidup yang berakhlak dan beragama, jika salah seorang diantaranya miskin, hendaklah memilih berdasarkan agamanya.

Pada dasarnya ayat-ayat Alquran dan hadits yang menyebutkan secara umum dalil yang mendasari pelaksanaan $k a f a ' a h$ dalam perkawinan, diantaranya terdapat dalam Alquran surat Al-Hujuraat: 13, yang berbunyi:

Hai manusia, sesungguhnya Kami menciptakan kamu dari seorang laki-laki dan seorang perempuan dan menjadikan kamu berbangsa-bangsa dan bersuku-suku supaya kamu saling kenal-mengenal. Sesungguhnya orang yang paling mulia diantara kamu disisi Allah ialah orang yang paling taqwa diantara kamu. Sesungguhnya Allah Maha mengetahui lagi Maha mengenal.

Dalam tafsir Ibnu Katsir Allah memberitahukan umat manusia, bahwa Allah telah menciptakan mereka dari satu jiwa dan telah menjadikan dari jiwa itu pasangannya, itulah Adam dan Hawa, dan Allah juga telah menciptakan mereka berbangsa-bangsa dan bersuku-suku. Maka kemuliaan manusia dipandang bertingkat-tingkat bila dilihat dari sudut keagamaan, seperti dalam hal ketaatan kepada Allah SWT dan kepatuhan kepada Rasul-Nya. ${ }^{26}$

Adapun sabab nuzulnya dalam tafsir Al-Mishbah menegaskan kesatuan asal usul manusia dengan menunjukkan kesamaan derajat manusia, tidak wajar seseorang berbangga dan merasa diri lebih tinggi dari yang lain, bukan saja antar satu bangsa, suku, atau warna kulit dengan selainnya, tetapi antar jenis kelamin mereka, karena seandainya ada yang berkata bahwa Hawwa yang perempuan itu bersumber dari tulang rusuk Adam, sedang Adam adalah laki-laki, dan sumber sesuatu itu lebih tinggi derajatnya dari cabangnya. Seperti dalam Alquran surat Al-Hujuraat/49:10, yang berbunyi:

Orang-orang beriman itu sesungguhnya bersaudara, sebab itu damaikanlah (perbaikilah hubungan) antara kedua saudaramu itu dan takutlah terhadap Allah, supaya kamu mendapat rahmat.

Ayat yang terkandung dalam firman Allah SWT yang artinya "Sesungguhnya orang-orang mukmin bersaudara" merupakan ketetapan syariat berkaitan dengan persaudaraan antara orang-orang mukmin. Hubungan kekeluargaan antara anak, bapak atau saudara, ada yang ditetapkan agama atau undang-undang serta memiliki dampak-dampak tertentu seperti hak kewarisan, nafkah, keharaman menikah dan lain-lain, dan ada juga yang

${ }^{26}$ Muhammad Nasib Ar-Rifa'i, Ringkasan Tafsir Ibnu Katsir, Jilid 4, Jakarta : Gema Insani Press, 2000, h. 437. 
ditetapkan hanya berdasarkan ketentuan umum yakni hubungan pertalian keturunan atau rahim..$^{27}$

Maka tidak diragukan bahwa semakin sama kedudukan laki-laki dengan kedudukan perempuan dalam perkawinan, keberhasilan hidup suami isteri semakin terjamin dan semakin terpelihara dari kegagalan rumah tangga. Sebagaimana disampaikan dalam Alquran surat An-Nur/24: 26, yang berbunyi:

Wanita-wanita yang keji adalah untuk laki-laki yang keji, dan laki-laki yang keji adalah untuk wanita-wanita yang keji (pula), dan wanita-wanita yang baik adalah untuk laki-laki yang baik dan laki- laki yang baik adalah untuk wanita-wanita yang baik (pula), mereka (yang dituduh) itu bersih dari apa yang dituduhkan oleh mereka (yang menuduh itu), bagi mereka ampunan dan rezki yang mulia (surga).

Pertimbangan $k a f a ' a h$ dalam perkawinan juga disandarkan pada hadits nabi yang diakui adanya kafa'ah dalam agama, maka diharamkan bagi seorang muslimah menikah dengan laki-laki kafir berdasarkan ijma' ulama :

Dari Ibnu Umar berkata: Rasulullah SAW bersabda, bangsa Arab itu sama derajatnya antara satu dengan yang lain, dan kaum Mawali (bekas hamba sahaya yang telah dimerdekakan) sama derajatnya antara satu dengan yang lain, kecuali tukang tenun dan tukang bekam. (H.R. Al-Hakim No.928).28

Hadits di atas sebagai dalil bahwa orang Arab sederajat dengan orang Arab lainnya, dan hamba sahaya tidak sederajat dengan mereka tapi sederajat dengan hamba sahaya lainnya. Para ulama berselisih pendapat perihal kafa'ah yang sebernarnya, dan yang paling kuat adalah pendapat Zaid bin Ali,Ibnu Sirin dan Umar bin Abdul Aziz, dan ini menjadi salah satu pendapat AnNashir bahwa kafa'ah yang diperhitungkan adalah kafa'ah dalam agama. ${ }^{29}$

Dari Abu Hurairah RA bahwa Nabi SAW bersabda, Wahai Bani Bayadhah, nikahilah Abu Hind, nikahlah dengannya, dan ia adalah tukang bekam. (H.R. Abu Dawud dan Al-Hakim dengan sanad jayyid (baik), No.930). ${ }^{30}$

Hadits ini merupakan salah satu dalil, bahwa faktor nasab bukanlah sebagai standar kafa'ah dalam pernikahan. Dalam riwayat yang shahih

${ }^{27}$ M. Quraish Shihab, Tafsir Al-mishbah, Jakarta: Lentera Hati, 2002, h. 247.

${ }^{28}$ Muhammad bin Ismail Al-Amir Ash-shan'ani, Subulus Salam, Jakarta: Darus Sunnah Press, 2011, No.928, h. 656.

${ }^{29} \mathrm{Ibid}, \mathrm{h} .657$.

${ }^{30}$ Muhammad bin Ismail Al-Amir Ash-shan'ani, Subulus Salam, No. 930, h. 660. 
dijelaskan, bahwa Bilal menikah dengan Halah binti Auf saudari Abdurrahman bin Auf dan Umar bin Al-Khatthab pernah menawarkan Hafshah kepada Salman Al-Farisi sebelum Rasulullah memperistrinya. Berkenaan dengan persamaan derajat antara sesama manusia dalam suatu pernikahan, terdapat beberapa contoh, diantaranya:

Rasulullah $S A W$ pernah meminang Zainab binti Jahsyin Al Qurasyiyyah, seorang wanita bangsawan, untuk Zaid bin Haritsah, mantan pembantu beliau. Abu Hudzaifah menikahkan Salim, seorang bekas budak dengan Hindun binti Al-Walid bin Utbah Rabi'ah. Rasulullah SAW menikahkan Miqdad dengan Dhaba'ah binti Zubair bin Abdul Muthalib dan Rasulullah $S A W$ juga pernah menikahkan Fathimah binti Qais Al-Fihriyyah dengan Usamah bin Zaid.

Imam Ali $R A$ pernah ditanya hukum pernikahan bagi orang-orang yang sekufu. Dia berkata, "sebagian manusia adalah sekufu bagi sebagian yang lain. Sama saja antara orang-orang Arab dan orang-orang non Arab, orangorang Quraisy dan orang-orang Bani Hasyim, apabila mereka memeluk Islam dan beriman." ${ }^{31}$ Dalam hal kafa'ah yang sangat dipertimbangkan dalam perkawinan yaitu terkait dengan faktor agama karena dalam hal nasab, harta maupun pekerjaan itu hanya sebagai pelengkap untuk membangun sebuah rumah tangga, jika tidak ada kriteria tersebut maka yang dipilih dalam hal agama, karena manusia tidak akan ada yang sempurna.

Ibnul Qayyim rahimahullah pun berkata "Adapun yang dikehendaki hukum adalah memasukkan unsur agama dalam kafa'ah sebagai hal dasar dan upaya mencapai kesempurnaan. karena itu hendaknya wanita shalehah tidak dinikahkan dengan lelaki yang suka berbuat keji. Alquran dan sunnah tidak mencermati hal selain agama dalam masalah kafa'ah" ${ }^{32}$

Adanya kafa'ah dalam perkawinan dimaksudkan sebagai upaya untuk menghindari terjadinya krisis rumah tangga. Keberadaannya dipandang sebagai aktualisasi nilai-nilai dan tujuan perkawinan. Dengan adanya kafa'ah (kesetaraan) dalam agama adalah satu-satunya syarat dalam pernikahan. Adapun dalam hal selain agama bukan merupakan syarat.

Masing-masing calon suami isteri dan para wali pihak wanita bebas memilih siapa saja yang dianggap sesuai atau sebanding dengan mempelai

\footnotetext{
${ }^{31}$ Sayyid Sabiq, Fiqih Sunnah 3, Jakarta: Pena Pundi Aksara, 2010, h. 400.

${ }^{32}$ Syaikh Mahmud Al-Mashri, Bekal Pernikahan, Jakarta: Qisthi Press, 2010, h. 270.
} 
wanita, yang dapat mempergaulinya dengan baik, dapat mewujudkan kestabilan dan keharmonisan rumah tangga, serta dapat menghindarkan faktor-faktor keretakan, bahaya dan penderitaan. Akan tetapi, jika mempelai wanita merelakan dirinya dinikahi seorang lelaki tanpa mempertimbangkan faktor keturunan, nasab, fisik dan sebagainya, maka pernikahannya dengan orang tersebut tetap sah dan tidak jadi persoalan.

Diantara kemungkaran yang biasa terjadi di tengah masyarakat, biasanya mereka lebih memilih dan mengutamakan orang-orang fasik daripada mukmin yang bertakwa, hanya karena harta berlimpah dan kedudukan tinggi dari orang tersebut, padahal bisa jadi pekerjaan orang fasik itu adalah pekerjaan yang haram, hartanya pun haram, serta jauh dari ketaatan kepada Allah. Para wali akan dimintai pertanggungjawaban dihadapan Allah atas tindakan mereka yang telah menelantarkan putri-putri mereka. Karena itu, hendaknya seorang wanita memilih lelaki yang berakhlak dan beragama. ${ }^{33}$

Islam memerintahkan masing-masing untuk memilih pasangan hidupnya atas dasar agama dan akhlak. Islam juga menganjurkan agar lelaki sekufu' dengan wanita dari segi nasab, kedudukan, kekayaan, dan profesi, dan Islam memerintahkan agar peminang melihat terlebih dahulu wanita pinangannya sebelum pernikahan dilangsungkan. Masalah ini sudah dibahas secara rinci dan tidak bisa diperdebatkan lagi. Memilih pasangan hidup berdasarkan kriteria di atas sangat jarang menimbulkan perselisihan di antara suami istri. ${ }^{34}$

Islam membenci pada setiap usaha yang akan merusak hubungan dalam perkawinan, karena dapat merusak dan menghilangkan kemaslahatan antara suami isteri. Kedamaian, ketentraman, kesejahteraan, kasih sayang dan keselamatan merupakan idaman setiap rumah tangga. Namun pasang surut, gelombang dan terkadang badai mungkin pula menimpa rumah tangga, sehingga harapan dan idaman tidak selalu dapat diraih. Kadang-kadang timbul problematika atau konflik dalam rumah tangga, di mana jika masalah

33 Syaikh Mahmud Al-Mashri, Bekal Pernikahan, h. 285.

${ }^{34}$ Syaikh Mahmud Al-Mashri, Perkawinan Idaman, Jakarta : Qisthi Press, 2010, h. 264. 
ini tidak dapat diatasi maka akan mengakibatkan perceraian atau putusnya perkawinan. ${ }^{35}$

Maka dari itu proses mencari jodoh memang tidak bisa dilakukan secara asal-asalan dan soal pilihan jodoh sendiri merupakan setengah dari suksesnya perkawinan.

\section{Teori Perkawinan}

Menurut bahasa nikah berarti penyatuan, diartikan juga sebagai akad atau hubungan badan yang sah. Selain itu, ada juga yang mengartikan dengan percampuran. $^{36}$ Sedangkan secara istilah pernikahan merupakan perjanjian antara laki-laki dan perempuan untuk menempuh kehidupan rumah tangga, sejak mengadakan perjanjian melalui akad kedua belah pihak telah terikat dan sejak itulah keduanya mempunyai kewajiban dan hak, yang sebelumnya tidak dimiliki. ${ }^{37}$

Al-Azhari mengatakan "akar kata nikah dalam ungkapan bahasa Arab berarti hubungan badan. Dikatakan pula, bahwa berpasangan juga merupakan salah satu dari makna nikah, karena menjadi penyebab adanya hubungan badan". Adapun menurut syari'at nikah juga berarti akad, sedangkan pengertian hubungan badan hanya merupakan metafora saja. ${ }^{38}$

Dalam Kamus Besar Bahasa Indonesia mengartikan kata "nikah" sebagai (1) perjanjian antara laki-laki dan perempuan untuk bersuami istri (dengan resmi) ${ }^{39}$; (2) perkawinan dalam Alquran menggunakan kata ini untuk makna tersebut, di samping secara majazi diartikannya sebagai "hubungan seks".

Pernikahan atau tepatnya "keberpasangan" merupakan ketetapan Ilahi atas segala makhluk. Berulang-ulang hakikat ini ditegaskan oleh Alquran antara lain dengan firman Allah dalam Alquran surat Al-dzariyat/51: 49, yang berbunyi:40 "Dan segala sesuatu Kami ciptakan berpasang-pasangan supaya

${ }^{35}$ Direktorat Urusan Agama Islam, Pembinaan Syariah, Direktorat Jenderal Bimas Islam Kementrian Agama RI, Etika Berkeluarga Bermasyarakat dan Berpolitik, Jakarta: Lajnah Pentashihan Mushaf Al-Qur'an, 2012, h. 344.

${ }^{36}$ Muhammad Fuad, Fiqih Wanita, Jombang: Lintas Media, 2007, h. 373.

${ }^{37}$ Beni Ahmad Saebani, Figh Munakahat 2, Bandung: Pustaka setia, 2001, h. 11.

${ }^{38}$ Muhammad Fuad, Fiqih Wanita, h. 373.

39 Tim Penyusun Kamus, Kamus Besar Bahasa Indonesia, Jakarta: Departemen Pendidikan dan Kebudayaan, 1991, h. 689.

${ }^{40}$ M. Quraish Shihab, Wawasan Al-Qur'an, Bandung: Mizan, 1999, h. 253. 
kamu menyadari (kebesaran Allah)." Serta terdapat juga dalam Alquran Surat Yasin/36: 36, yaitu: "Maha suci Tuhan yang telah menciptakan pasanganpasangan semuanya, baik dari apa yang ditumbuhkan oleh bumi dan dari diri mereka maupun dari apa yang tidak mereka ketahui."

Di samping definisi di atas dalam Kompilasi Hukum Islam menambah penjelasan, dengan rumusan sebagai berikut " Perkawinan menurut Islam adalah pernikahan yang sangat kuat atau mitsagan ghalizhan untuk menaati perintah Allah dan melaksanakannya merupakan ibadah". ${ }^{41}$ Dalam pandangan Islam di samping perkawinan sebagai perbuatan ibadah, juga merupakan sunnah Allah dan sunnah Rasul. Sunnah Allah, berarti menurut qudrat dan iradat Allah suatu tradisi yang telah ditetapkan oleh Rasul untuk dirinya sendiri dan untuk umatnya.

Sifatnya sebagai sunnah Allah dapat dilihat dari rangkaian ayat-ayat sebagai berikut: (1) Allah menciptakan makhluk ini dalam bentuk berpasangpasangan; (2) secara khusus pasangan itu disebut laki-laki dan perempuan; (3) laki-laki dan perempuan itu dijadikan berhubungan dan saling melengkapi dalam rangka menghasilkan keturunan yang banyak; (4) perkawinan itu dijadikan sebagai salah satu ayat-ayat atau tanda-tanda dari kebesaran Allah. ${ }^{42}$

Ta'rif pernikahan ialah akad yang menghalalkan pergaulan dan membatasi hak dan kewajiban serta tolong menolong antara seorang laki-laki dan seorang perempuan yang bukan mahram. Nikah adalah salah satu asas pokok hidup yang paling utama dalam pergaulan atau masyarakat yang sempurna. Pernikahan itu bukan saja merupakan satu jalan yang amat mulia untuk mengatur kehidupan rumah tangga dan keturunan, tetapi juga dapat dipandang sebagai satu jalan menuju pintu perkenalan antara suatu kaum dengan kaum lain, dan perkenalan itu akan menjadi jalan untuk menyampaikan pertolongan antara satu dengan yang lainnya. ${ }^{43}$

Perkawinan juga bertujuan agar setiap pasangan suami isteri dapat meraih kebahagiaan dengan pengembangan potensi mawaddah dan rahmah, sehingga dapat melaksanakan tugas kekhalifahan dalam pengabdian kepada

${ }^{41}$ Undang-Undang Republik Indonesia Nomor 1 tahun 1974, Perkawinan dan Kompilasi Hukum Islam, Bandung:Citra Umbara, 2012, h. 324.

${ }^{42}$ Amir Syarfuddin, Hukum Perkawinan Islam di Indonesia, Jakarta: Prenada Media Grup, 2006, h. 41.

${ }^{43}$ Sulaiman Rasjid, Fiqh Islam, Bandung: Sinar Baru Algensindo, 2012, h. 374. 
Allah SWT yang darinya lahir fungsi-fungsi yang harus diemban oleh keluarga. Diadakan akad nikah adalah untuk selama-lamanya hingga suami isteri meninggal dunia, karena yang diinginkan oleh Islam adalah langgengnya kehidupan perkawinan.

Suami isteri bersama-sama dapat mewujudkan rumah tangga sebagai tempat berlindung, menikmati naungan kasih sayang dan dapat memelihara anak-anaknya hidup dalam pertumbuhan yang baik agar anak-anak itu bisa menjadi generasi yang berkualitas. Oleh karena itu, ikatan antara suami isteri adalah ikatan yang paling suci dan teramat kokoh. ${ }^{44}$

Islam sangat menyukai perkawinan, banyak sekali ayat-ayat Alquran dan hadits-hadits Nabi Saw yang memberikan anjuran untuk menikah, di antaranya Qur'an surat Ar-Rum: 21, yang berbunyi:

Dan di antara tanda-tanda kekuasaan-Nya ialah Dia menciptakan untukmu isteri-isteri dari jenismu sendiri, supaya kamu cenderung dan merasa tenteram kepadanya, dan dijadikan-Nya diantaramu rasa kasih dan sayang. Sesungguhnya pada yang demikian itu benar-benar terdapat tanda-tanda bagi kaum yang berfikir.

Dalil di atas merupakan nash Alquran yang menganjurkan kepada manusia untuk melakukan pernikahan, karena di dalam pernikahan itu sendiri jika manusia mau merenungi, terdapat banyak tanda-tanda kekuasaan Allah.

Di dalam hadits-hadits juga tak kalah banyaknya dalil yang menganjurkan untuk melakukan pernikahan, salah satunya hadits riwayat imam Bukhari dan Muslim “dari Anas $R A$ ada tiga orang berkunjung kerumah-rumah istri Rasulullah $S A W$ menanyakan tentang ibadahnya Nabi $S A W$ setelah mendapat jawaban mereka menganggap sedikit ibadah nabi. Mereka berkata, bagaimana kita ini, padahal beliau telah diampuni dosanya, baik yang lampau dan yang akan datang. Salah seorang diantara mereka berkata, saya akan shalat tahajud setiap malam. Lainnya mengatakan, saya akan berpuasa sepanjang tahun, tidak akan berhenti, yang lainnya berkata lagi, saya akan menjauhi wanita, saya tidak akan menikah selamanya. Kemudian Rasulullah $S A W$ bersabda : ${ }^{5}$

${ }^{44}$ Direktorat Urusan Agama Islam, Pembinaan Syariah, Direktorat Jenderal Bimas Islam Kementrian Agama RI, Etika Berkeluarga Bermasyarakat dan Berpolitik, Jakarta: Lajnah Pentashihan Mushaf Al-Qur'an, 2012, h. 343.

${ }^{45}$ H.S.A. Alhamdani, Risalah Nikah, Jakarta: Pustaka Amani, 1989, h. 16. 
Dari Annas bin Malik RA bahwa Nabi SAW bersabda, bertahmid dan memuji Allah dengan hamdalah ketika mendengar 3 kelompok tersebut yang sedang gaduh, dan beliau berkata : (tetapi aku shalat tahajjud tiap malam, dan tidur, dan berpuasa lalu berbuka, dan menikahi perempuan, barang siapa yang membenci sunnah-ku maka bukan dari golongan-ku). (Mutaffaq Alaih No. 994). ${ }^{46}$

Serta terdapat dalam hadits lainnya tentang anjuran untuk menikah, yaitu:

Dari Abdullah bin Mas'ud RA berkata: bahwasannya Rasulullah SAW bersabda. Wahai para pemuda, barang siapa yang telah mampu hendaklah menikah, sebab menikah akan lebih menundukkan pandangan dan lebih menjaga kehormatan, kalau belum mampu harap berpuasa, karena puasa akan menjadi perisai baginya. (Mutaffaq Alaih No.993). ${ }^{47}$

Berbagai riwayat di atas menunjukkan dengan jelas, bahwa pernikahan memang dianjurkan bahkan bukan sekedar dianjurkan karena merupakan sunnatullah yang pelaksanaannya dipastikan membawa kebaikan yang demikian banyak ditinjau dari berbagai sisi kehidupan manusia.

\section{Prinsip-prinsip dan Tujuan dasar perkawinan}

Prinsip-prinsip dasar perkawinan Islam yang harus diketahui dapat dirumuskan sebagai berikut:

a. Dalam memilih calon suami/istri, faktor agama/akhlak calon harus menjadi pertimbangan pertama sebelum keturunan, rupa, dan harta, sebagaimana diajarkan oleh Rasul.

b. Bahwa nikah atau hidup berumah tangga itu merupakan sunnah Rasul bagi yang sudah mampu. Dalam kehidupan berumah tangga terkandung banyak sekali keutamaan yang bernilai ibadah, menyangkut aktualisasi diri sebagai suami/istri, sebagai ayah/ibu dan sebagainya. Bagi yang belum mampu diperintahkan untuk bersabar dan berpuasa, tetapi jika dorongan nikah sudah tidak terkendali padahal ekonomi belum siap sementara takut terjerumus pada perzinaan maka agama menyuruh agar menikah saja, insya Allah 200.

46 Al-Hafidz bin Hajar Asqalani, Bulughul Maram, Surabaya: Darrul Ilmu, No. 994, h. ${ }^{47}$ Ibid, No. 993, h. 200. 
rezeki akan datang kepada orang yang memiliki semangat menghindari dosa, entah dari mana datangnya.

c. Bahwa tingkatan ekonomi keluarga itu berhubungan dengan kesungguhan berusaha, kemampuan mengelola dan berkah dari Allah SWT. ${ }^{48}$

d. Suami istri itu bagaikan pakaian bagi pemakainya, antara keduanya harus ada kesesuaian ukuran, kesesuaian mode, asesoris dan pemeliharaan kebersihan. Layaknya pakaian, masing-masing suami isteri harus bisa menjalankan fungsinya sebagai penutup aurat (sesuatu yang memalukan) dari pandangan orang lain, pelindung dari panas dinginnya kehidupan, dan kebanggaan keindahan dari pasangannya. Dalam keadaan tertentu pakaian mungkin bisa diperkecil, dilonggarkan, ditambah asesoris dan sebagainya. Mengatasi perbedaan selera, kecenderungan dan hidup antara suami isteri diperlukan pengorbanan kedua belah pihak.

e. Bahwa cinta dan kasih sayang (mawaddah dan rahmah) merupakan sendi dan perekat rumah tangga yang sangat penting. Cinta adalah sesuatu yang suci, anugerah Tuhan dan sering tidak rasionil. Cinta dipenuhi nuansa memaklumi dan memaafkan, kesetiaan, kesabaran, pengertian, pemberian dan pengorbanan akan mendatangkan atau menyuburkan cinta, sementara penyelewengan, egoisme, kikir dan kekerasan akan menghilangkan rasa cinta.

f. Bahwa salah satu fungsi perkawinan adalah untuk menyalurkan hasrat seksual secara sehat, benar dan halal. Hubungan suami isteri (persetubuhan) merupakan hak azasi, kewajiban dan kebutuhan bagi kedua belah pihak. Persetubuhan yang memenuhi tiga syarat (sehat, benar, halal) itulah yang berkualitas dan dapat mendatangkan ketentraman (sakinah). ${ }^{49}$

g. Bahwa pergaulan dalam rumah tangga juga membutuhkan suasana dinamis, dialog dan saling menghargai.

h. Bahwa perkawinan itu bukan hanya mempertemukan dua orang (suami isteri), tetapi juga dua keluarga besar antar besan. Oleh karena

${ }^{48}$ Helmi Anshori, Menuju Rumah Tangga Sakinah, Jakarta: Departemen Agama, 2004, h. 133.

${ }^{49}$ Helmi Anshori, Menuju Rumah Tangga Sakinah, h. 136. 
itu, suami dan isteri harus bisa berhubungan secara proporsioanal dengan kedua belah pihak keluarga, orangtua, mertua, adik, ipar, dan seterusnya.

i. Bahwa karena selalu berdekatan, komunikasi antara suami isteri biasanya menjadi sangat intens. Keharmonisan hubungan antara suami isteri dipengaruhi oleh kesamaan atau keseimbangan watak/tempramen, kesamaan hobi, kedekatan visi dan sebagainya. Keharmonisan suami dan isteri akan terwujud jika masing-masing berpikir untuk memberi bukan untuk menuntut, saling menghargai bukan saling merendahkan. Dalam kehidupan, seringkali dijumpai bahwa kesulitan yang dihadapi justru mengandung hikmah yang besar, asal orang dapat menerima dan menghadapinya secara benar dan sabar..$^{50}$

Selain dari prinsip-prinsip yang telah disebutkan, tujuan perkawinan adalah melanjutkan dan memelihara keturunan manusia. Firman Allah dalam Alquran Surat An-Nisa'/4: 1, yang berbunyi:

Hai sekalian manusia, bertakwalah kepada Tuhan-mu yang telah menciptakan kamu dari seorang diri, dan dari padanya Allah menciptakan isterinya, dan dari pada keduanya Allah memperkembang biakkan laki-laki dan perempuan yang banyak, dan bertakwalah kepada Allah yang dengan (mempergunakan) nama-Nya kamu saling meminta satu sama lain, dan (peliharalah) hubungan silaturrahim. Sesungguhnya Allah selalu menjaga dan mengawasi kamu.

\section{Keharmonisan Rumah Tangga}

Keharmonisan rumah tangga merupakan dambaan setiap pasangan suami istri, karena dalam keharmonisan itu terbentuk hubungan yang hangat antar anggota keluarga dan juga merupakan tempat yang menyenangkan untuk hidup. Adapun pengertian tentang keharmonisan rumah tangga akan dipaparkan sebagai berikut.

Secara terminologi keharmonisan berasal dari kata harmonis yang berarti serasi, selaras. Titik berat dari keharmonisan adalah keadaan selaras atau serasi, keharmonisan bertujuan untuk mencapai keselarasan dan

\footnotetext{
${ }^{50}$ Helmi Anshori, Menuju Rumah Tangga Sakinah, h. 140.
} 
keserasian dalam kehidupan. Keluarga perlu menjaga kedua hal tersebut untuk mencapai keharmonisan. ${ }^{51}$

Keharmonisan merupakan kedamaian, ketentraman, kesejahteraan, kasih sayang, dan keselamatan yang menjadi idaman setiap rumah tangga. Sehubungan dengan itu, agar pasangan suami isteri dapat membina rumah tangga harmonis yang diridhai oleh Allah SWT maka pasangan tersebut harus menjaga etika yang telah ditetapkan Alquran, yang merupakan hak dan kewajiban masing-masing dalam rumah tangga. Suami sebagai kepala keluarga hendaknya melaksanakan tanggung jawabnya, masing-masing pasangan saling mencintai dan menyayangi, saling pengertian dan saling menghormati. ${ }^{52}$

Menurut Yusuf Qardhawi: “Ciri-ciri yang menonjol dalam keluarga muslim tetaplah dominan kesetiaan, ketaatan, kasih sayang, dan membina silaturahmi, disamping itu dalam rumah tangga muslim mempunyai ciri-ciri menjaga akhlak mulia yang senantiasa mengikuti tuntunan Alquran dan hadits". ${ }^{53}$

Begitu juga dalam pandangan Alquran tentang etika kehidupan dalam berkeluarga, suami istri dituntut menjaga hubungan yang baik, menciptakan suasana yang harmonis, yaitu dengan menciptakan saling pengertian, saling menjaga, saling menghormati dan saling menghargai serta saling memenuhi kebutuhan masing-masing pasangan suami istri.

Apabila suami isteri melalaikan tugas dan kewajiban maka akan terjadi kesenjangan hubungan yang akibatnya dapat menimbulkan berbagai masalah, seperti mengakibatkan kesalahpahaman, perselisihan dan ketegangan hidup berumah tangga. Oleh karena itu, antara suami isteri harus selalu menjaga etika dalam berkeluarga, yaitu selalu menjaga keselarasan, keserasian, dan keseimbangan hubungan baik secara batiniah dan lahiriah dengan melaksanakan tugas dan kewajiban masing-masing pasangan yang disertai dengan tolong menolong dan saling pengertian dalam melaksanakan

51 Tim Penyusun Kamus, Kamus Besar Bahasa Indonesia, Jakarta: Departemen Pendidikan dan Kebudayaan, 1991, h. 342.

${ }^{52}$ Direktorat Urusan Agama Islam, Pembinaan Syariah, Direktorat Jenderal Bimas Islam Kementrian Agama RI, Etika Berkeluarga Bermasyarakat dan Berpolitik, Jakarta: Lajnah Pentashihan Mushaf Al-Qur'an, 2012, h. 344.

53 Direktorat Urusan Agama Islam, Pembinaan Syariah, Direktorat Jenderal Bimas Islam Kementrian Agama RI, Etika Berkeluarga Bermasyarakat dan Berpolitik, h. 360. 
tugas dan kewajiban masing-masing, karena lembaga perkawinan bertujuan membentuk keluarga bahagia dan sejahtera sesuai dengan ajaran Islam, dengannya dapat terwujud keluarga harmonis. ${ }^{54}$ Seperti dalam firman Allah Alquran Surat Ar-Rum: 21, yang berbunyi:

Dan di antara tanda-tanda kekuasaan-Nya ialah Dia menciptakan untukmu isteri-isteri dari jenismu sendiri, supaya kamu cenderung dan merasa tenteram kepadanya, dan dijadikan-Nya diantaramu rasa kasih dan sayang. Sesungguhnya pada yang demikian itu benar-benar terdapat tanda-tanda bagi kaum yang berfikir.

Dari beberapa definisi tentang keharmonisan rumah tangga yang dikemukakan di atas, maka penulis dapat menyimpulkan bahwa keharmonisan adalah keadaan rumah tangga dimana para anggotanya merasa bahagia, saling mencintai dan saling menghormati serta dapat mengaktualisasikan diri sehingga perkembangan anggota keluarga berkembang secara normal.

Maka dari itu, kehidupan rumah tangga yang penuh cinta kasih tersebut dalam Islam disebut mawaddah-warahmah, yaitu keluarga yang tetap menjaga perasaan cinta, cinta terhadap suami isteri, cinta terhadap anak dan juga cinta pekerjaan. Perpaduan cinta suami isteri akan menjadi landasan utama dalam berumah tangga. Islam mengajarkan agar suami memerankan tokoh utama dan isteri memerankan peran lawan yaitu menyeimbangkan karakter suami.

Rumah tangga sering diibaratkan dengan bahtera atau kapal yang sedang berlayar di samudera yang luas, dalam perjalanannya akan menghadapi suasana cuaca yang baik, air laut tenang, angin semilir yang membuat hati ikut senang dan gembira, lautan yang luas bagaikan hamparan permadani biru yang menyejukkan mata memandang, ikan-ikan laut yang melompat-lompat kelihatan kilatan sisiknya, sungguh suasana yang sangat indah mempesona hati. Namun, terkadang ombak yang menggulung-gulung, badai atau topan yang menghempaskan kapal ke kanan dan ke kiri, yang membuat kapal menjadi oleng bahkan menjadi keram, inilah perumpaan rumah tangga yang sedang dibangun bagaikan bahtera di tengah lautan. ${ }^{55}$

Rumah tangga juga sebagai jalinan cinta dan kasih sayang, sehingga dapat menciptakan ketenangan dalam kehidupan, pancaran rasa bahagia

\footnotetext{
${ }^{54} \mathrm{Ibid}$, h. 345.

${ }^{55}$ Ibdalsyah, Baiti Jannati, Bogor: Gema Insani, 2014, h. 110
} 
tercermin diwajah ahli keluarga. Suami menjadi imam, sosok yang melindungi dan disegani, ucapan dan perintahnya diikuti dengan seksama, nasehat-nasehat menjadi pedoman dalam kehidupan.

Sang isteri menjadi pendamping suami dalam menjalankan mahligai rumah tangga, siap menerima kepemimpinan suami, keberadaannya menjadi penenang bagi suami dan anak-anaknya, tatapan matanya yang penuh kelembutan memberikan semangat kepada suami dan anak-anak dalam beraktifitas menjalankan pekerjaannya. Menciptakan suasana rumah yang menyenangkan dan penuh keakraban dan penuh dengan kasih sayang, inilah rumah tangga yang menjadi surga bagi penghuninya. ${ }^{56}$

Sebuah keluarga merupakan konsep yang bersifat multidimensi. Para ilmuan sosial bersilang pendapat mengenai rumusan definisi keluarga yang bersifat universal. Salah satu ilmuan yang permulaan mengkaji keluarga adalah George Murdock. Dalam bukunya Social Strukture, Murdock menguraikan bahwa keluarga merupakan kelompok sosial yang memiliki karakteristik tinggal bersama, terdapat kerja sama ekonomi, dan terjadi proses reproduksi. Dengan kata lain definisi keluarga adalah rumah tangga yang memiliki hubungan darah atau perkawinan atau menyediakan terselenggaranya fungsi-fungsi instrumental mendasar dan fungsi-fungsi ekspresif keluarga bagi para anggotanya yang berada dalam suatu jaringan.

Pada umumnya, fungsi yang dijalankan oleh keluarga seperti melahirkan dan merawat anak, menyelesaikan masalah, dan saling peduli antar anggotanya tidak berubah substansinya dari masa ke masa. Pada dasarnya keluarga yang utuh dalam perkawinan yang sah lebih menjamin kesejahteraan anak. Walaupun demikian, proses yang berlangsung dalam keluarga lebih besar pengaruhnya terhadap akibat-akibatnya pada diri anak, seperti rendahnya perilaku dalam kepuasan hidup.

Proses dalam keluarga tersebut mencakup proses yang terjadi dalam relasi pasangan, relasi orangtua-anak dan relasi kakak-adik atau lebih spesifik berupa kelekatan orang tua-anak, supervisi orang tua kepada anak dan perilaku kontrol dalam pengasuhan. ${ }^{57}$ Dinamika kehidupan keluarga itu begitu banyak dengan tantangan. Tekad untuk meraih kebahagiaan bersama ketika memulai kehidupan rumah tangga ternyata bukanlah perjalanan tanpa rintangan, seberat apapun persoalan yang dihadapi sebuah rumah tangga

\footnotetext{
56 Ibid, h. 119.

${ }^{57}$ Sri Lestari, Psikologi Keluarga, Jakarta: Kencana, 2012, h. 3.
} 
pada dasarnya dapat diatasi jika suami dan istri mau duduk bersama dan membicarakan persoalan mereka secara terbuka.

Kunci kelanggengan perkawinan adalah keberhasilan melakukan penyesuaian diantara pasangan. Penyesuaian ini bersifat dinamis dan memerlukan sikap dan cara berpikir yang luwes. Penyesuaian adalah proses interaksi yang kontinu dengan diri sendiri, orang lain, dan lingkungan. Keberhasilan penyesuaian dalam perkawinan tidak ditandai dengan tiadanya konflik yang terjadi. Penyesuaian yang berhasil ditandai oleh sikap dan cara yang konstruktif dalam melakukan resolusi konflik. Banyak kajian yang telah dilakukan untuk mengetahui faktor-faktor yang mempengaruhi kualitas perkawinan.

Istilah kualitas perkawinan biasanya dipadankan dengan kebahagiaan perkawinan atau kepuasan perkawinan, keduanya sama-sama menunjuk pada suatu perasaan positif yang dimiliki pasangan dalam perkawinan yang maknanya lebih luas daripada kenikmatan, kesenangan, dan kesukaan. Keberhasilan membangun kebersamaan dalam pelaksanaan kewajiban keluarga menjadi salah satu indikasi bagi keberhasilan penyesuaian pasangan..$^{58}$

Membina rumah tangga akan berhasil tergantung dari penyesuaian antara kedua belah pihak, maka kedua belah pihak harus memperhatikan tali temali perekat pernikahan, yakni cinta, mawaddah, rahmah, dan amanah Allah, itulah tali temali ruhani perekat perkawinan, sehingga apabila cinta pupus dan mawaddah putus, masih ada rahmat dan kalau pun tidak tersisa masih ada amanah, dan selama pasangan itu beragama, amanahnya akan terpelihara. ${ }^{59}$

Mawaddah adalah kelapangan dada dan kekosongan jiwa dari kehendak buruk, yang mempunyai nilai cinta plus. Ini disebabkan hatinya begitu lapang dan kosong dari keburukan sehingga pintu-pintunya pun telah tertutup untuk dihinggapi keburukan lahir bathin yang mungkin datang dari pasangannya. Rahmah adalah kondisi psikologis yang muncul di dalam hati akibat menyaksikan ketidakberdayaan, sehingga mendorong yang bersangkutan untuk memberdayakannya. Karena itu dalam kehidupan keluarga, masing-masing suami isteri akan bersungguh-sungguh bahkan bersusah payah demi mendatangkan kebaikan bagi pasangannya serta

\footnotetext{
${ }^{58}$ Sri Lestari, Psikologi Keluarga, h. 10

${ }^{59}$ M. Quraish Shihab, Wawasan Al-Qur'an, Bandung: Mizan, 1999, h. 276.
} 
menolak segala hal yang dapat mengganggu dan mengeruhkan pasangannya. ${ }^{60}$

Alquran menggaris bawahi hal ini dalam rangka jalinan perkawinan karena betapa pun hebatnya seseorang pasti memiliki kelemahan, dan betapa pun lemahnya seseorang pasti ada juga unsur kekuatannya. Suami dan isteri tidak luput dari keadaan tersebut, sehingga suami dan isteri harus berusaha untuk saling melengkapi.

Pernikahan juga merupakan amanah yang digaris bawahi oleh Rasulullah $S A W$ bahwa amanah adalah sesuatu yang diserahkan kepada pihak lain disertai dengan rasa aman dari pemberinya, karena kepercayaannya bahwa apa yang diamanatkan, akan dipelihara dengan baik, serta keberadaannya aman ditangan yang diberi amanah. Isteri adalah amanah dipelukan suami, suami pun amanah dipangkuan isteri. Tidak mungkin orangtua dan keluarga masing-masing pasangan akan merestui perkawinan tanpa adanya rasa percaya dan aman.

Suami dan isteri tidak akan menjalin hubungan tanpa merasa aman dan percaya kepada pasangannya. Kesediaan seorang isteri untuk hidup bersama dengan seorang laki-laki, meninggalkan orangtua dan keluarga yang membesarkannya, dan mengganti semua itu dengan penuh kerelaan untuk hidup bersama laki-laki asing yang menjadi suaminya serta bersedia membuka rahasianya yang paling dalam, semua itu merupakan hal yang sungguh mustahil, kecuali jika merasa yakin bahwa kebahagiaan bersama suami akan lebih besar dibanding kebahagiaan dengan orangtua. Keyakinan inilah yang dituangkan isteri kepada suaminya dan itulah yang dinamai Alquran mitsaqan ghalidzhan (perjanjian yang amat kokoh). ${ }^{61}$

Menciptakan rumah tangga yang harmonis perlu diterapkan aturanaturan cinta, demi hubungan yang indah dalam perkawinan pasangan harus mengetahui dan mengikuti aturan yang ada. Sekalipun tidak semua orang senang mendengarkan dan mengikuti aturan, namun harus diakui bahwa aturan inilah yang membuat mereka bisa berbahagia.

Bagian terbaiknya, aturan ini akan menjaga agar pasangan bisa tetap nyaman dan fokus dalam menjalani hubungan. Jangan menyembunyikan rahasia apapun diantara berdua, aturan dasar ini harus diikuti agar kemudian

\footnotetext{
60 M. Quraish Shihab, Wawasan Al-Qur'an, h. 277.

${ }^{61}$ M. Quraish Shihab, Wawasan Al-Qur'an, h. 278.
} 
hari tidak menimbulkan penyesalan atau hal yang menyakitkan. Jangan menyembunyikan tekanan kerja, bila sedang memiliki masalah ungkapkan saja pada pasangan, hal ini akan membuat pasangan jadi lebih toleran dan mau mengerti apa yang sedang dirasakan.

Berusahalah tetap saling setia, jangan pernah beralih pada hubungan lain ketika merasa bosan. Kejenuhan adalah hal yang biasa dialami pasangan, namun mencari orang ketiga bukanlah jalan keluarnya. ${ }^{62}$ Selalu memberi dukungan satu sama lain sangatlah penting bagi pasangan disaat terbaik dan terburuk, dukungan itulah yang dibutuhkan untuk membuat cinta semakin awet, serta memanjakan dan menumpahi dengan rasa kasih sayang, bukan berarti mengekang dan membuatnya merasa tertekan, namun memberikan rasa nyaman dan dicintai adalah bekal agar tidak ada orang ketiga dan kejenuhan.

Jadilah pendengar yang baik, jangan hanya ingin didengarkan sendiri saja, mendengarkan kekasih adalah latihan kesabaran paling sederhana yang akan mempersiapkan ketika bertemu masalah yang lebih besar nanti setelah menikah, dan selalu hormati privasi satu sama lain, ini juga menjadi salah satu dasar berhubungan asmara agar kepercayaan dan rasa nyaman tetap terjaga, Pujian, ucapan terimakasih, dan permintaan maaf adalah yang sangat penting di dalam hubungan, karena keseimbangan ketiga hal ini membuat satu sama lain nyaman dan merasa percaya diri.

Aturan-aturan tersebut adalah resep utama dalam membina hubungan asmara agar semakin kuat dan mengikat, hubungan akan lebih menyenangkan dan cinta yang telah dibina bersama akan selalu terjaga dalam menjalani suatu bahtera kehidupan rumah tangga. ${ }^{63}$

Selain menerapkan aturan-aturan cinta untuk kebahagiaan, sebuah rumah tangga juga memerlukan prinsip yang perlu dipegang guna membangun rumah tangga yang bahagia. Di antaranya:

\section{a. Agama atau Falsafah hidup}

Meyakini falsafah hidup yang sama semakin memperkuat tali bathin keluarga. Menjalani ritual agama bersama membuat harmoni keluarga terjalin lebih hangat. Pahami kebersamaan keluarga sebagai bagian dari falsafah

\footnotetext{
${ }^{62}$ Nilam Sari, Kiat Mendapatkan Pasangan Hidup Yang Tepat, Yogyakarta : Araska, 2014, h. 156.

${ }^{63}$ Ibid, h. 157.
} 
hidup yang bermakna. Ajak dan libatkan anak dalam acara keagamaan. Kegiatan seperti itu akan membantunya untuk menyadari hal-hal yang lebih mendasar dalam hidup, sebuah kecerdasan spiritual yang jelas sangat berpengaruh pada kesanggupan seseorang untuk bahagia. ${ }^{64}$

b. Tumbuhkan komitmen

Jika kebahagiaan dipahami sebagai sebuah pilihan, maka modal pertama untuk mendapatkannya tentulah kemauan untuk bahagia. Kebahagiaan sebuah keluarga berawal dari adanya komitmen dari masingmasing pihak untuk membangun rumah tangga yang bahagia. Tanpa komitmen, kesulitan dan persoalan mudah sekali menghancurkan keluarga. Upaya membangun kebahagiaan keluarga kehilangan fondasi, ibarat membangun istana kertas yang kemudian roboh ditiup angin.

c. Memberi apresiasi

Setelah membangun komitmen bersama ke arah kebahagiaan, modal berikutnya yang diperlukan adalah kemampuan untuk menyatukan kekuatan dari masing-masing pihak. Sebuah kolaborasi harus dibangun atas sikap yang positif akan kemampuan masing-masing pasangan. Tanpa kesediaan untuk melihat hal-hal positif pada pasangan maka tidak akan ada sinergi yang tulus ke arah kebahagiaan. ${ }^{65}$

\section{d. Pelihara Kebersamaan}

Pondasi berikutnya yang diperlukan untuk meraih kebahagiaan rumah tangga adalah kebersamaan. Luangkan waktu untuk bersama, bermain bersama, bekerja bersama, berlibur bersama. Kebersamaan merupakan sebuah momen untuk saling berbagi (a moment for sharing), serta melahirkan perasaan saling membutuhkan dan saling melengkapi. Sebuah hubungan yang didasarkan pada perasaan saling membutuhkan secara positif akan menjadi awal yang baik bagi sebuah kebahagiaan bersama yang ingin diraih.

\section{e. Berkomunikasi}

Komunikasi adalah sebuah proses pertukaran makna guna melahirkan pengertian bersama. Sebuah komunikasi baru dapat dikatakan terjadi jika kedua belah pihak atau lebih yang terlibat dalam proses komunikasi h. 8 .

${ }^{64}$ Mulia Moeslim, Membangun Keluarga Bahagia, Jakarta : Pustaka Sinar Harapan, 2006, ${ }^{65}$ MuliaMoeslim, Membangun Keluarga Bahagia, h. 4. 
mencapai pemahaman bersama. Sebuah komunikasi dapat dikatakan sukses jika masing-masing pihak membagi makna yang sama. Komunikasi jelas akan melahirkan pertautan perasaan atau emosi yang kuat diantara mereka yang terlibat. Karena itu guna meraih kebahagiaan rumah tangga, sebaiknya komunikasikan berbagai peristiwa penting yang dialami agar semakin mengenal dan merasa dilibatkan dalam dunia masing-masing pihak.

f. Bermain dan humor

Manusia seringkali digambarkan sebagai homo ludens (makhluk yang suka dengan permainan). Bermain merupakan salah satu ciri khas manusia dibandingkan makhluk yang lain. Sediakan waktu untuk bermain, bersantai, rilek, dan humor. Melalui permainan dapat membagi perasaan yang dimiliki dengan sesama anggota keluarga. Permainan melahirkan tawa dan canda, halhal sederhana namun teramat penting untuk kebahagiaan.

g. Berbagi tanggung jawab

Fleksibel dalam berbagi peran dan tanggung jawab. Kadang suami yang menemani anak, kadang istri yang sibuk diluar. Berbagi peran dan tanggung jawab membuat masing-masing pihak semakin merasa sebagai satu kesatuan. ${ }^{66}$

h. Miliki kepentingan dan kegemaran bersama

Untuk memperkuat fondasi bagi kebersamaan keluarga, sebaiknya carilah kegemaran dan kepentingan yang sama disetiap anggota keluarga. Lalu merencanakan bersama untuk menjalani kegemaran dan kepentingan itu. Kegemaran itu bisa dalam bentuk yang ringan (berlibur) sampai yang berat (bisnis atau aktivitas politik). Merencanakan, menjalankan, dan mengevaluasi kegiatan itu secara bersama semakin menguatkan kesatuan keluarga.

i. Tahan dengan Problem

Tidak ada satupun keluarga di dunia ini yang sepenuhnya bebas dari problem. Jika kesulitan datang dalam kehidupan rumah tangga maka jangan pernah sungkan untuk meminta bantuan dari pihak yang lebih ahli untuk mengatasinya. Kekuatan dan kemampuan dalam menghadapi hidup tidak akan dikurangi sedikitpun jika berkemauan meminta bantuan pihak lain.

${ }^{66}$ MuliaMoeslim, Membangun Keluarga Bahagia, h. 9. 
Kesepuluh prinsip yang diuraikan ini tampak sederhana dan boleh dibilang merupakan hal yang umumnya sudah diketahui, yang menjadi kunci bukanlah seberapa sederhana dan umumnya kesepuluh prinsip ini, melainkan seberapa besar kemauan pasangan suami isteri untuk menghadirkan dan membiasakan kesepuluh prinsip ini dalam hidup keseharian rumah tangga. Jika ingin membangun sebuah rumah tangga yang bahagia maka sepuluh prinsip sebaiknya dikembangkan dalam kehidupan perkawinan. ${ }^{67}$

Dari penjelasan tersebut bahwa $k u f u^{\prime}$ dalam perkawinan yaitu laki-laki sebanding dengan calon isterinya, sederajat dalam akhlak, sama dalam kedudukan, sebanding dalam tingkat sosial dan kekayaan. Sebenarnya kafa'ah tidak termasuk syarat sah pernikahan tetapi merupakan hak bagi seorang calon mempelai wanita dan walinya. Tetapi dalam kondisi tertentu, kafa'ah juga bisa dikatakan sebagai syarat sah pernikahan.

Dengan kata lain, dalam kondisi normal hanya sebagai penyempurna. Walaupun hanya sebagai penyempurna, pernikahan yang terjadi tanpa mengindahkan unsur-unsur kafa'ah akan mengakibatkan berbagai macam problematika dalam pernikahan, bahkan bisa mengarah ke perceraian. Sudah dimengerti bahwa kafa'ah bukanlah syariat yang wajib dipenuhi dalam perkawinan, melainkan kafa'ah juga merupakan satu aturan hidup manusia untuk menjamin kemaslahatan hidup.

Oleh karena itu, terdapat perselisihan para ulama tentang masalah $k a f a ' a h$. Sebagian ulama mendukung konsep kafa'ah sebagai satu syarat untuk berumah tangga dan ada yang berpendapat tidak perlunya kafa'ah untuk mendirikan rumah tangga kecuali dari segi agama dan akhlaknya saja. Hal ini berdasarkan dalil-dalil dan hujjah yang diyakini oleh masing-masing pihak.

Telah disebutkan pada pembahasan di atas tentang beberapa faktor yang ditetapkan oleh Fuqoha, faktor-faktor tersebut merupakan syarat yang ideal, sebab faktor-faktor tersebut adalah sebagai jaminan kebahagiaan dan kesejahteraan hidup berumah tangga. Namun, keadaan manusia tidak selalu sesempurna yang diidealkan dan selalu banyak kekurangan, sehingga jarang sekali didapati seorang calon suami atau calon isteri yang memiliki faktorfaktor tersebut secara menyeluruh. Apabila faktor-faktor tersebut tidak dimiliki dan didapati seluruhnya, maka yang harus diutamakan adalah faktor

${ }^{67}$ MuliaMoeslim, Membangun Keluarga Bahagia, h. 10. 
agama, karena akan memberikan kedamaian hati dan keharmonisan dalam rumah tangga.

\section{Konsep Kafa'ah Dalam Perkawinan Terhadap Keharmonisan Rumah Tangga}

Permasalahan tentang kesepadanan (kafa'ah) dalam perkawinan memang merupakan problema utama dalam proses pemilihan calon jodoh atau pasangan hidup. Untuk itu konsep kafa'ah dalam perkawinan harus menjadi tela'ah yang cukup serius bagi para calon pasangan. Islam akan berbicara mengenai jodoh atau perkawinan yang seimbang antara suami dan istri, kemudian keseimbangan yang dimaksud bukan keseimbangan dalam pengertian materi, sebagaimana yang ditafsirkan oleh golongan material, melainkan keseimbangan dalam segala hal.

Selain itu juga Islam mengajarkan untuk mencari jodoh yang seimbang dalam kejiwaan, kesehatan, akhlak serta keyakinan. Kemudian penilaian ini ditekankan oleh Islam supaya nantinya bisa melahirkan anak-anak yang dapat tertampung di dalam keluarga yang shaleh, baik demi pertumbuhan atau pendidikannya. ${ }^{6}$

Syariat Islam juga mengajarkan untuk berhati-hati dalam memilih pasangan hidup, karena berumah tangga bukan untuk waktu yang tertentu saja lalu bercerai, hendaknya pernikahan untuk selama-lamanya sampai akhir hayat, tujuannya agar tidak terjadi penyesalan dikemudian hari lalu banyak pihak yang terdzalimi, terutama anak-anak.

Seorang muslim atau muslimah harus selalu ingat bahwa pasangannya kelak adalah orang yang dengan kerelaan hatinya untuk hidup berumah tangga, yang harus ikhlas bersama-sama berjuang untuk menyempurnakan sebagian imannya. Oleh karena itu, harus memiliki kriteria yang dianjurkan dalam syariat. ${ }^{69}$

Rasulullah $S A W$ bersabda:

${ }^{68}$ Labib Mz, Aqis Bil Qisthi, Risalah Figh Wanita, Surabaya: Bintang Usaha Jaya, 2005, h. 336 .

69 Abu Muhammad Ibnu Shalih bin Hasbullah, Sejak Memilih, Meminang Hingga Menikah, Bogor: Tim Pustaka Ibnu 'Umar, 2014, h. 5. 
Seorang wanita dinikahi karena empat hal: 1) karena hartanya, 2) karena keturunan (nasabnya), 3) karena kecantikkannya, dan 4) karena agamanya. Pilihlah wanita yang taat beragama, niscaya engkau akan berbahagia. (HR. Bukhari No. 798). ${ }^{70}$

Para ulama telah menetapkan kriteria-kriteria untuk menetapkan $k u f u^{\prime}$ tidaknya seseorang. Dalam menetapkan kriteria ini para ulama berbeda pendapat mengenai eksistensi maupun kriterianya. Masing-masing ulama mempunyai batasan yang berbeda mengenai masalah ini. Jika diamati, perbedaan ini terjadi karena adanya perbedaan pandangan dalam menilai sejauh mana kriteria-kriteria kafa'ah yang mempunyai kontribusi dalam melestarikan kehidupan rumah tangga. Kriteria-kriteria tersebut dapat dijabarkan sebagai berikut:

\section{Agama dan akhlak}

Sekelompok ulama berpendapat bahwa soal $k u f u^{\prime}$ perlu diperhatikan, tetapi yang menjadi ukuran $k u f u^{\prime}$ ialah sikap hidup yang lurus dan sopan. Laki-laki yang shaleh walaupun keturunannya rendah berhak untuk menikah dengan wanita yang berderajat tinggi, laki-laki fakir berhak menikah dengan wanita yang kaya raya, dengan syarat bahwa pihak lelakinya adalah seorang muslim yang menjauhkan dirinya dari meminta-minta dan tidak seorang pun yang menghalangi atau menuntut pembatalan. Kecuali jika perempuan yang shaleh dikawinkan oleh bapaknya dengan laki-laki yang fasik, sedangkan perempuan itu masih gadis dan dipaksa oleh orangtuanya, maka berhak untuk menuntut pembatalan. ${ }^{71}$

Memilih pasangan yang satu akidah merupakan kewajiban bagi seorang muslim yang akan melangsungkan pernikahan, orang tua atau walinya yang akan menikahkan anaknya, telah diperintahkan Allah agar menikahkan puterinya dengan laki-laki muslim atau menikahkan putranya dengan perempuan muslimah, dan dilarang menikahkan keduanya dengan yang non Muslim.

Hal ini menunjukkan bahwa pernikahan adalah syariat Islam yang sangat penting bagi kaum muslimin, dengan memilih pasangan yang satu

\footnotetext{
70 Imam Al-Mundzir, Shahih Muslim, Jakarta: Pustaka Amani, 2003, h. 436.

71 Sayyid Sabiq, Fiqh Sunnah 7, Bandung: PT Alma'arif, 1997, h. 37
} 
akidah berarti akan membawanya ke syurga yang dijanjikan Allah di akhirat nanti. ${ }^{72}$ Firman Allah SWT dalam surat An-Nur/24: 26, yang berbunyi:

"Wanita-wanita yang keji adalah untuk laki-laki yang keji, dan laki-laki yang keji adalah untuk wanita-wanita yang keji (pula), dan wanita-wanita yang baik adalah untuk laki-laki yang baik dan laki- laki yang baik adalah untuk wanita-wanita yang baik (pula), mereka (yang dituduh) itu bersih dari apa yang dituduhkan oleh mereka (yang menuduh itu), bagi mereka ampunan dan rezki yang mulia (surga)."

Para ulama mazhab Maliki juga berpendapat, “apabila seorang perawan dinikahkan oleh ayahnya dengan seorang laki-laki fasik, maka perempuan memiliki hak untuk menolak pernikahan".

Para penganut pendapat ini bersandar kepada dalil-dalil Alquran yang terdapat dalam Alquran surat Al-Hujurat ayat 13, yang berbunyi:

Hai manusia, sesungguhnya Kami menciptakan kamu dari seorang laki-laki dan seorang perempuan dan menjadikan kamu berbangsa-bangsa dan bersuku-suku supaya kamu saling kenal-mengenal. Sesungguhnya orang yang paling mulia diantara kamu di sisi Allah ialah orang yang paling takwa diantara kamu. Sesungguhnya Allah Maha mengetahui lagi Maha mengenal.

Dimana ayat ini menetapkan bahwa semua manusia sama dari segi penciptaan dan nilai kemanusiaan. Tidak seorang pun lebih mulia daripada orang lain, kecuali dari segi ketakwaan kepada Allah SWT, yaitu dengan menunaikan hak Allah dan hak manusia. ${ }^{73}$

Ibnu Qayyim berpendapat, "bahwa hal yang ditunjukkan oleh hukum Rasulullah $S A W$ adalah kafa'ah yang diukur degan pokok agama dan kesempurnaannya saja. Seorang perempuan muslim tidak boleh dinikahkan dengan seorang laki-laki kafir, dan seorang perempuan yang menjaga kesucian dirinya tidak boleh dinikahkan dengan seorang laki-laki yang durhaka".

Alquran dan As-Sunnah pun tidak memperhitungkan kafa'ah dengan perkara lain. Alquran mengharamkan seorang perempuan muslim untuk menikah dengan seorang pezina, serta tidak memperhitungkan nasab, kekayaan atau kecantikan. Karena dalam rumah tangga jika mempunyai agama dan akhlak yang mulia, maka akan menjamin daya tahan kesetiaan,

\footnotetext{
${ }^{72}$ Ibdalsyah, Baiti Jannati, Bogor: Gema Insani, 2014, h. 18

${ }^{73}$ Sayyid Sabiq, Fiqih Sunnah 3, Jakarta: Pena Pundi Aksara, 2010, h. 399.
} 
senantiasa memudahkan dan meringankan segala beban hidup yang dihadapi, dengan saling memuliakan, saling mencintai, saling menghargai serta saling pengertian yang dimiliki keduanya tidak akan saling menyakiti dalam membina rumah tangga yang bahagia.

Sementara itu, para ulama mazhab Syafi'i, Maliki, Hanafi dan Hambali berpendapat bahwa kafa'ah diukur dengan keistiqamahan dan keshalehan semata, tetapi sebagian Fuqaha ada yang memandang pada perkara-perkara lain yang harus diperhitungkan seperti harta, nasab dan fisik. ${ }^{74}$

2. Segi Nasab/Keturunan

Orang-orang Arab adalah sekufu' antar mereka. Begitu juga, orangorang Quraisy. Laki-laki non Arab tidak sekufu' bagi perempuan Arab, dan laki-laki Arab (selain dari suku Quraisy) tidak sekufu' bagi perempuan Quraisy. Para ulama madzhab Syafi'i dan Hanafi tidak memperselisihkan pengukuran kafa'ah dengan nasab. Tetapi mereka berbeda pendapat tentang tingkatan antar orang-orang Quraisy.

Para Ulama Madzhab Hanafi berpendapat bahwa laki-laki Quraisy (selain dari bani Hasyim) adalah sekufu' bagi perempuan dari bani Hasyim. Adapun menurut para ulama madzhab Syafi'i, bahwa laki-laki Quraisy (selain dari bani Hasyim dan bani Muthalib) tidak sekufu' bagi perempuan dari bani Hasyim dan bani Muthalib. ${ }^{75}$

Sesungguhnya ajaran Islam berlainan dengan pendapat tersebut, karena Nabi $S A W$, ternyata menikahkan kedua puterinya sendiri dengan Utsman bin Affan dan menikahkan Zainab dengan Abdul Ash bin Rabi', sedang keduanya adalah dari suku Abdusy Syam. Ali pun menikahkan puterinya dengan Umar, sedangkan Umar sendiri dari suku Adawi, ketahuilah bahwa pengetahuan orang ada di atas tingkat keturunan dan segala bentuk kehormatan. Jadi, seorang alim adalah $k u f u^{\prime}$ dengan semua perempuan yang nasabnya rendah, bahkan sekalipun nasabnya tidak diketahui. Allah SWT berfirman dalam surat Az-Zumar/39: 9, yakni:

(Apakah kamu hai orang musyrik yang lebih beruntung) ataukah orang yang beribadat di waktu-waktu malam dengan sujud dan berdiri, sedang ia takut kepada (azab) akhirat dan mengharapkan rahmat Tuhannya? katakanlah: "adakah sama orang-orang yang mengetahui dengan orang-orang yang tidak

\footnotetext{
74 Sayyid Sabiq, Fiqh Sunnah 3, h. 401.

${ }^{75}$ Ibid, h. 402.
} 
mengetahui?" sesungguhnya orang yang berakallah yang dapat menerima pelajaran.

Hal ini sehubungan dengan sesama bangsa Arab dengan bangsabangsa lain di luar Arab, ada pendapat yang mengatakan bahwa mereka tidak kufu' dengan bangsa Arab lantaran keturunan.

Diriwayatkan oleh Syafi'i bahwa kufu' sesama bangsa Non Arab, diukur dengan bagaimana keturunan-keturunan mereka, dengan diqiyaskan antara suku-suku bangsa Arab yang satu dengan lainnya, karena menganggap perbuatan tercela apabila seorang perempuan dari satu suku menikah dengan laki-laki dari lain suku yang lebih rendah nasabnya. Jadi, hukumnya sama dengan hukum yang berlaku di kalangan bangsa Arab karena sebabnya adalah sama. ${ }^{76}$

Terdapat juga dalam hadits nabi $S A W$ yang menyuruh Bani Bayadhah untuk menikahi Abu Hindun tukang bekam yang bunyinya:

Dari Abu Hurairah RA bahwa Nabi SAW bersabda, wahai Bani Bayadhah, nikahilah Abu Hind, nikahlah dengannya, dan ia adalah tukang bekam. (H.R. Abu Dawud dan Al-Hakim dengan sanad jayyid (baik), No.930). ${ }^{77}$

Bahwasannya beliau mengingatkan tentang persamaan yang dimaksud adalah sama-sama beragama Islam bukan karena keturunan. Dalam masalah ini, kebanyakan manusia mempunyai pendapat yang anehaneh dan tidak ada dalilnya sama sekali, kecuali hanya sekedar untuk kesombongan dan membangga-banggakan diri, tidak ada Rabb yang berhak disembah selain Allah semata. Banyak sekali wanita muslimah yang gagal menikah dikarenakan kesombongan para wali yang membangga-banggakan keturunan. ${ }^{78}$

\section{Harta/Kekayaan}

Para ulama dari madzhab Syafi'i berbeda pendapat dalam masalah kekayaan, sebagian ada yang menjadikannya ukuran kufu'. Seperti, orang fakir menurut mereka tidak kufu' dengan perempuan yang kaya. Sebagaimana

${ }^{76}$ Sayyid Sabiq, Figh Sunnah 7, Bandung: PT Alma'arif, 1997, h. 44.

${ }_{77}$ Muhammad bin Ismail Al-Amir Ash-shan'ani, Subulus Salam, Jakarta: Darus Sunnah, 2011, No. 930, h. 660.

${ }^{78} \mathrm{Ibid}, \mathrm{h} .659$. 
riwayat Samarah bahwa Rasulullah $S A W$ bersabda: Kebangsawanan adalah pada kekayaan dan kemuliaan pada taqwa. (H.R. Tirmidzi). ${ }^{79}$

Mereka juga mengatakan bahwa kemampuan laki-laki fakir dalam menafkahi istrinya adalah di bawah ukuran laki-laki kaya. Sebagian lagi berpendapat bahwa kekayaan itu tidak dapat menjadi ukuran kufu', karena kekayaan sifatnya naik turun, dan bagi perempuan yang berbudi luhur tidaklah mementingkan kekayaan tersebut.

Adapun golongan Hanafi menganggap bahwa kekayaan yang menjadi ukuran kufu', yaitu "memiliki harta untuk memberikan mahar dan nafkah, bagi orang yang tidak memiliki harta untuk membayar mahar dan memberikan nafkah, atau salah satu di antaranya, maka dianggap tidak $k u f u^{\prime}$. Yang dimaksud dengan kekayaan untuk memberi mahar adalah sejumlah uang yang dapat dibayarkan dengan tunai dari mahar yang diminta".

Abu Yusuf menilai bahwa "kekayaan adalah dari kesanggupannya memberi nafkah bukan mahar, karena dalam urusan mahar biasanya yang sering mengada-ada saja, dan seorang laki-laki dianggap mampu memberi nafkah dengan melihat kekayaan orang tuanya".

Demikian juga pendapat Ahmad, "jika perempuan yang kaya berada di tangan suami yang miskin, maka akan menyebabkan kemudharatan bagi suami, sebab akan mengalami kesulitan dalam memenuhi nafkahnya dan jaminan anak-anaknya". .0

Apabila pernikahan dilandasi dengan kekayaan maka rumah tangga yang dibinanya akan mudah goyah, karena harta pada masanya akan habis, dan mudah sekali mendatangkan kehancuran.

4. Tidak cacat fisik

Salah satu syarat $k u f u$ ' adalah tidak ada kecacatan, hal ini menurut pendapat murid-murid Syafi'i dan riwayat Ibnu Nashr dari Malik. Bagi lakilaki yang mempunyai cacat jasmani yang mencolok, maka tidak kufu' dengan perempuan yang sehat dan normal. Jika cacatnya tidak begitu mencolok, tetapi kurang disenangi secara pandangan lahiriyah, seperti buta, tangan butung, atau perawakannya jelek, dalam hal ini ada dua pendapat.

79 Sayyid Sabiq, Fiqh Sunnah 7, h. 46.

${ }^{80}$ Slamet Abidin, Aminuddin, Figh Munakahat, Bandung: CV Pustaka Setia, 1999, h. 60. 
Rauyani berpendapat bahwa laki-laki seperti yang disebutkan tidaklah $k u f u^{\prime}$ dengan perempuan yang sehat, tetapi golongan Hanafi dan Hambali tidak menerima pendapat ini. ${ }^{81}$

Dalam kitab Al-Mughni dikatakan: "kecacatan tidak menjadi ukuran $k u f u$ ', karena pernikahan orang cacat itu tidak batal, hanya pihak perempuan mempunyai hak untuk menerima dan menolak, bukan walinya. Karena yang menempuh resikonya adalah perempuan, tetapi wali boleh mencegahnya jika perempuan itu menikah dengan orang gila, tangannya buntung atau kehilangan jari-jarinya."

Hal ini berkaitan dengan penampilan dalam memilih calon suami atau isteri. Memilih pasangan hidup, jika hanya memperhatikan kecantikan atau ketampanan fisik akan mudah musnah ditelan usia, karena jika pernikahan dilandasi dengan penampilan maka akan berpengaruh terhadap rumah tangga yang dibinanya. Setelah usia semakin tua maka tidak akan ada lagi saling menghargai dan menyayangi di setiap perjalanan kehidupan rumah tangganya. ${ }^{82}$

Status Kufu' diukur ketika berlangsungnya akad nikah, dan jika selesai akad nikah terjadi kekurangan dalam salah satu sifat kafa'ah, maka hal itu tidaklah mengubah keadaan, dan tidak berpengaruh pada akad nikah, karena sekufu' bukan termasuk syarat nikah.

Jika pada waktu akad nikah pekerjaan suami dipandang terhormat dan mampu memberi nafkah istrinya atau orang yang shaleh, namun dikemudian hari keadaannya berubah menjadi orang hina, tidak mampu memberi nafkah atau fasik dari perintah Allah, maka status akad nikahnya tetap sah. Bila terjadi suami semacam ini, maka isteri hendaklah bersabar dan bertakwa kepada Allah, karena dengan sabar dan takwa kepada Allah SWT, niscaya pertolongan akan datang. ${ }^{83}$

Dasar yang menjadi pijakan seseorang menikah seharusnya karena melihat agama dan budi pekerti calon pasangan hidup. Hal ini berlaku sebagai peringatan bagi wali untuk tidak sembarangan menjodohkan anaknya, sebab jika tidak kebetulan dijalan yang benar sudah tentu seolaholah menghukum atau merusak akhlak dan jiwa anak yang tidak bersalah.

\footnotetext{
${ }^{81}$ Sayyid Sabiq, Fiqh Sunnah 7, h. 47.

82 Slamet Abidin, Aminuddin, Figh Munakahat, h. 61.

${ }^{83}$ Syaikh Sulaiman Ahmad Yahya Al-Faifi, Ringkasan Figh Sunnah Sayyid Sabiq, Jakarta: Pustaka Al-Kautsar, 2013, h. 459.
} 
Pertimbangkan lebih dahulu dengan sedalam-dalamnya antara manfaat dan mudharatnya yang bakal terjadi dihari kemudian. ${ }^{84}$

Bukan hal yang mengherankan jika kini banyak terjadi, orang menikah hanya sekedar untuk melampiaskan dan mengumbar nafsu birahi. Kawincerai menjadi budaya, hingga tidak ada ketentraman dalam berumah tangga. Mereka memandang, bahwa hidup adalah uang dan kemegahan.

Harta, tahta dan wanita sebagai tolak ukur keberhasilan dalam mengarungi hidup, hingga dalam memilih jodoh selalu mengutamakan kekayaan material, keturunan, dan kecantikkan. Hal tersebut merupakan prestise (kemampuan seseorang) dalam mengarungi kehidupan di tengah masyarakat.

Agama dan akhlak bukan lagi dijadikan ukuran, bahkan menjadi cemoohan. Dengan harta dan tahta, merasa hidup lebih aman dan tenteram, terlepas dari belenggu kemiskinan dan kehinaan. Ada pula orang yang menikah hanya sekedar mencari ajang penyaluran seks, sekedar mencari kenikmatan dan kepuasan duniawi, indahnya lekuk tubuh wanita yang menggiurkan senantiasa dijadikan dambaan dalam memilih pasangan hidup.

Memilih pasangan hidup hanya karena memenuhi keinginan nafsu merupakan racun yang tidak boleh terlintas dalam benak seorang muslim. Harus disadari, bahwa pembentukkan keluarga mutlak harus diarahkan pada terciptanya keluarga yang Islami. Bahkan Islam memandang sebagai proyek besar yang tentu saja butuh keseriusan dalam mewujudkannya, karena di dalam Islam dijumpai pokok-pokok yang sangat rinci dan akurat tentang tata cara memilih pasangan hidup. Ditegaskan tentang pentingnya kehidupan umat Islam yang harus dijiwai dengan sifat yang terkandung dalam kitab Alquran, hingga dikemudian hari dapat menjadi contoh teladan bagi manusia diseluruh penjuru dunia. ${ }^{85}$

Dalam pandangan Islam, masalah pernikahan mendapatkan perhatian khusus, lebih-lebih dalam memilih pasangan hidup, sehingga rumah tangga yang dibangun benar-benar kokoh dan bahagia. Sebab pembinaan rumah tangga juga berdampak pada keselamatan, kebahagiaan individu,

${ }^{84}$ Beni Ahmad Saebani, Fiqh Munakahat 2, Bandung : CV Pustaka Setia, 2001, h. 204.

85 A.Mudjab Mahalli, Menikahlah, Engkau Menjadi Kaya, Yogyakarta: Mitra Pustaka, 2001, h. 84 . 
masyarakat, serta kemaslahatan dan kemuliaan umat manusia secara keseluruhan.

Dalam masalah yang multikompleks ini, Islam tidak pernah menganggap norma-norma material lainnya dan fenomena yang menarik lainnya sebagai sesuatu yang penting. Namun, Islam memberikan landasan yang sangat mendasar bagi tercapainya sebuah bangunan rumah tangga yang bahagia, sejahtera, penuh kedamaian dan ketentraman. ${ }^{86}$ Maka dari itu, konsep kafa'ah dalam perkawinan dalam memilih suami dan istri sebagai pendamping, hendaklah memperhatikan dasar-dasar yang telah digariskan syariat Islam.

Bilamana kaum muslimin bersedia memperhatikan serta mempraktekkan kaidah-kaidah dalam memilih suami istri sesuai dengan apa yang telah digariskan syariat Islam, maka keluarga bahagia sejahtera akan mudah tercapai, tentu akan memperoleh keberuntungan yang luar biasa, baik berupa ketenangan lahir maupun bathin, serta ketahanan dan kekokohan dalam menghadapi tantangan hidup maupun pengaruh negatif yang muncul. ${ }^{87}$

Untuk mengetahui kualitas calon istri atau calon suami, dilihat dari adanya standar untuk menilai kualitas tersebut. Standar yang harus digunakan adalah standar yang diberikan syariat Islam. Para ulama telah merumuskan dalam karangan-karangan mereka tentang standar kualitas calon istri dan calon suami, rumusan tersebut bersandar pada nash-nash seputar kehidupan rumah tangga. Maka dari itu perlu diperhatikan oleh setiap muslim dalam memilih istri, di antranya yaitu:

a. Memiliki kebaikan agama

Faktor kebaikan agama akan menjadikannya sebagai wanita shalehah. Rasulullah SAW memerintahkan agar faktor ini menjadi faktor utama. Wanita shalehah merupakan hal yang paling banyak memberikan manfaat kebaikan setelah ketakwaan kepada Allah SWT, bahkan wanita shalehah yang menjadi seorang istri, seakan Allah telah membantu orang tersebut dalam menutup sebagian agamanya dan tinggal bertakwa kepada Allah dalam sebagian yang

${ }^{86} \mathrm{Ibid}$, h. 85.

${ }^{87}$ A. Mudjab Mahalli, Menikahlah, Engkau Menjadi Kaya, h. 85. 
lain. Maka jika faktor ini terdapat pada diri seorang wanita, hendaklah seseorang jangan berpaling dari faktor tersebut dan memilih faktor lain. ${ }^{88}$

b. Wanita yang subur dan penyayang

Kesuburan dipengaruhi oleh faktor genetik. Oleh karena itu, faktor kesuburan dapat diduga dari keadaan ibunya atau wanita yang ada dikeluarganya. Namun, secara fisik memang tidak sepenuhnya dapat diduga berdasarkan jumlah anak atau jumlah saudaranya. Sedangkan sifat penyayang wanita dapat diketahui dari komentar atau cerita orang-orang yang dekat dengan wanita tersebut. Bisa juga diketahui dari alam pertumbuhannya, karena sifat penyayang bukan sifat bawaan dari lahir, melainkan sifat dan karakter hasil dari pendidikan sejak masa kecil.

c. Berasal dari keluarga yang dikenal baik agamanya dan bersikap qana'ah

Jika seorang wanita berasal dari keluarga yang baik agamanya dan memiliki qana'ah. Pengarang Subul As-Salam menjelaskan, yang dimaksud alnasab adalah perbuatan-perbuatan atau karakter baik yang dinisbahkan kepada keturunan laki-laki. Namun, dapat di perluas bahwa wanita yang bernasab baik yaitu berasal dari keluarga yang dikenal kebaikannya, bukan didasarkan pada kebangsawanannya.

Maka hendaklah wanita yang bernasab baik, berasal dari keluarga yang baik-baik, yakni berasal dari keluarga yang berbudi luhur, karena dengan begitu diharapkan wanita itu juga memiliki budi luhur seperti keluarganya. ${ }^{89}$

d. Menyejukkan dan mendatangkan kesenangan atau kebahagiaan

Hendaknya wanita yang akan dinikahi dapat menyejukkan, menyenangkan dan menenteramkan jiwa. Faktor ini ada kaitannya dengan faktor kecantikkan fisik, karena kecantikkan fisik wanita bisa membuat suaminya nyaman dan membuat suami menundukkan pandangannya dari wanita lain, serta akan mendapatkan kesempurnaan cinta dari suami. Faktor ini bukan hanya berkaitan dengan keindahan fisik semata, dan kecantikkan fisik bagi setiap orang bisa saja berbeda-beda.

Seorang wanita bagi seseorang bisa dianggap cantik dan bagi orang lain mungkin dianggap biasa saja atau tidak cantik. Nampaknya faktor tersebut

\footnotetext{
88 Yahya Abdurrahman, Risalah Khitbah, Bogor: Al Azhar Press, 2013, h. 121.

${ }^{89}$ Yahya Abdurrahman, Risalah Khitbah, h. 123.
} 
justru lebih berkaitan dengan bagaimana wanita itu mengurus dirinya, keadaan seperti itu yang menjadikan wanita enak dipandang. Ketika seorang suami memandang isteri yang pandai mengurus diri, menjaga kerapihan dan kebersihan, tidak bermuka masam, tentu suami akan merasakan kesenangan, merasa bahagia dan tentram jiwanya..$^{90}$

Istri ibarat tempat tinggal dan kebun bagi suami, teman mengarungi kehidupan, ratu rumah tangga, ibu dari anak-anak, pelabuhan hati, dan tempat yang akan memberinya kesenangan dan keselamatan. Istri merupakan komponen paling penting di dalam sebuah rumah tangga, dari rahimnya anak-anak dilahirkan, kemudian mewarisi berbagai macam sifat dan keistimewaan, belajar mengembangkan potensi dan mengerti bahasa, serta meniru adat dan kebiasaan dalam berperilaku.

Dalam rengkuhan kasih sayang seorang istri (ibu), naluri seorang anak terbina, begitu pula dengan agama dan jiwa sosialnya. Oleh karena itu, Islam selalu menekankan pentingnya suami dalam memilih istri yang shalehah, dan menjadikannya sebaik-baik perhiasan.

Barang siapa yang memiliki kehendak untuk menikah maka harus berhati-hati dalam menentukkan pilihan. Istri shalehah adalah istri yang taat beragama, berpegang teguh kepada keutamaan-keutamaan dalam berperilaku, dalam memenuhi hak suami, dan mengayomi anak-anak mereka. Selain hal-hal tersebut, Islam selalu memperingatkan laki-laki yang sedang mencari pasangan hidup agar kriteria terhadap calon isterinya tidak terlepas dari unsur-unsur kebajikan.

Sebagian besar orang lebih tertarik kepada perempuan yang memiliki harta yang banyak, kecantikkan yang menggoda, pangkat dan kedudukan maupun kemuliaan nasab dan orangtua tanpa memperhatikan kesempurnaan akhlak dan baiknya pola didik yang diterima. Pada akhirnya, rumah tangga yang dibina atas dasar itu hanya akan mendatangkan kesedihan dan berakhir dengan hal-hal yang tidak mengenakkan bagi kedua pihak. ${ }^{91}$

Sebagaimana tuntunan dan bimbingan yang diberikan kepada seorang laki-laki dalam memilih istri, Islam memberikan perhatian pula terhadap seorang perempuan yang akan memilih suami. Demikian pula kepada wali

\footnotetext{
90 Yahya Abdurrahman, Risalah Khitbah, h. 125.

91 Sayyid Sabiq, Fiqih sunnah 3, Jakarta: Pena Pundi Aksara, 2010, h. 211.
} 
nikah, dianjurkan agar memilihkan calon suami yang shalih bagi putrinya, tidak boleh sembarangan dalam memilihkan pasangan.

Keharusan wali memilihkan pasangan yang shalih, agar pihak perempuan benar-benar selektif dalam memilihkan pasangan. Sebab bagi seorang laki-laki apabila tidak cocok dengan pilihannya, maka dengan mudah untuk menceraikan istrinya, kemudian mencari ganti yang lebih cocok. Lain halnya bagi seorang perempuan yang tidak mampu berbuat dengan demikian. Karena itu, Islam menganjurkan kepada kaum perempuan maupun para wali agar ekstra ketat dalam memilih calon suami, sehingga dikemudian hari dapat menjaga kewajiban terhadap suami secara baik. ${ }^{92}$

Kemudian, dalam memilih suami sebagai pendamping, hendaklah memperhatikan dasar-dasar yang telah digariskan syariat Islam. Bilamana kaum muslimin bersedia memperhatikan serta mempraktekkan kaidahkaidah dalam memilih suami dengan sesuai yang telah digariskan syariat Islam, maka rumah tangga yang harmonis akan mudah tercapai. Serta akan memperoleh keberuntungan yang luar biasa, baik berupa ketenangan lahir maupun bathin, serta ketahanan dan kekokohan dalam menghadapi tantangan hidup maupun pengaruh negatif yang muncul. Maka yang perlu diperhatikan oleh setiap muslimah dalam memilih suami adalah:

a. Berakhlak baik dan agamanya kuat

Asas pertama ini merupakan faktor terpenting dalam memilih suami, sebab Islam adalah agama fitrah dan bermoral yang sudah pasti mengedepankan kesucian, kemuliaan dan akhlak. Dalam memilih laki-laki yang akan diajak mengarungi bahtera hidup berumah tangga harus selektif dan teliti, harus memilih laki-laki yang shalih. ${ }^{93}$

Laki-laki yang bertakwa dan berakhlak baik akan memperlakukan isterinya dengan baik, sesuai dengan yang dikehendaki Allah, serta mampu menjalankan kewajibannya memimpin keluarga, menjadi teladan yang baik bagi lingkungan, dan menjalankan kewajiban-kewajibannya sebagai suami bagi istrinya, juga sebagai ayah untuk anak-anaknya, menjaga kehormatan

${ }_{92}$ A. Mudjab Mahalli, Menikahlah, Engkau Menjadi Kaya, Yogyakarta: Mitra Pustaka, 2001, h. 100.

${ }^{93} \mathrm{Ibid}, \mathrm{h} .102$. 
keluarga dengan berusaha keras menjamin kebutuhan-kebutuhan rumah tangga. ${ }^{94}$

b. Utamakan yang $k u f u^{\prime}$

Kufu' yakni yang setara kedudukannya, terutama dalam urusan agama. Namun, patut dipertimbangkan pula kesetaraan dalam nasab, profesi, maupun kedudukan sosial dan ekonomi, karena hal ini akan lebih menjaga perasaan masing-masing dan lebih melancarkan komunikasi diantara kedua suami isteri.

Pasangan yang $k u f u^{\prime}$ akan lebih mudah untuk saling beradaptasi dalam rangka menciptakan satu langkah bersama menuju keutuhan dan kemajuan rumah tangga. Tujuan mencari yang kufu' agar seorang wanita tidak tersia-siakan sehingga hidup menderita. Akan tetapi, apabila agamanya telah $k u f u^{\prime}$ dan ridho terhadap keadaan calon suaminya dalam hal nasab, profesi, ekonomi dan yang lainnya, maka hal ini tidak menjadi masalah dan semoga mendapat pertolongan Allah.

c. Mencintai dan menerima calon isteri dengan apa adanya

Yang penting adalah kecintaannya tersebut tidak membutakan dari kebenaran, adapun jika cinta belum tumbuh sempurna, maka hendak berusaha untuk saling memupuk kecintaan tersebut dalam rumah tangga. Sehingga Allah akan menanamkan kecintaan yang luar biasa kepada pasangan yang ikhlas. ${ }^{95}$ Islam menetapkan suami sebagai pemimpin bagi keluarganya, suami bertanggung jawab memelihara kepentingan dan kemaslahatan anggota keluarganya.

Jika suami mampu melakukan kewajibannya untuk mengatur dan memelihara berbagai urusan, kepentingan dan kemaslahatan anggota keluarganya, maka keluarga akan menjadi keluarga yang bahagia. Calon suami harus memiliki bekal yang baik dan cukup untuk melakukan kewajibannya. Karena merupakan syarat bagi terbentuknya rumah tangga yang harmonis dan keluarga yang bahagia. ${ }^{96}$

Suami yang terpuji dalam pandangan Islam ialah yang memiliki sifatsifat kemanusiaan yang utama, sifat kejantanan yang sempurna, dan

${ }_{94}$ Abu Muhammad Ibnu shalih bin Hasbullah, Sejak Memilih,Meminang Hingga Menikah, h. 18.

${ }^{95} \mathrm{Ibid}, \mathrm{h} .19$.

${ }^{96}$ Yahya Abdurrahman, Risalah khitbah, h. 133. 
memandang kehidupan dengan benar, melangkah pada jalan yang lurus, bukanlah orang yang memiliki kekayaan atau orang yang memiliki fisik yang baik dan kedudukan tinggi, tanpa memberi pertolongan dengan memberikan anugerah dan unsur yang baik.

Bagi para pemudi hendaknya memperhatikan yang utama yaitu akhlak dan agama yang kuat, karena disisi suami terdapat kebahagiaan serta keamanan istri. Dan hendaknya istri tidak dipertontonkan pada orang lain atau menipu dengan berbagai penampilan. ${ }^{97}$

Dari pembahasan tersebut dapat disimpulkan bahwa konsep kafa'ah terhadap keharmonisan rumah tangga dalam menentukan atau memilih pasangan hidup harus penuh dengan kehati-hatian agar terciptanya suatu tujuan perkawinan yang diharapkan dalam rumah tangga.

Dalam hal ini, kriteria untuk memilih pasangan hidup yang harus diutamakan yaitu aspek keagamaan dan akhlak yang baik di antara calon suami dan calon isteri, sehingga konsep kafa'ah dalam membangun suatu bahtera rumah tangga dapat menciptakan rasa aman dan nyaman serta kebahagiaan. Sedangkan aspek-aspek yang lainnya hanya sebagai pelengkap, karena kriteria-kriteria tersebut tidak mungkin didapati secara sempurna.

Secara sederhana penulis ingin mencoba menawarkan alternatif rasional pemecahan persoalan. Pertama, dalam menentukan pemilihan pasangan hendaknya mampu berfikir secara mendalam tentang makna filosofis dari sebuah perkawinan, dari sini akan muncul sebuah keinginan seseorang dalam memilih kriteria pasangan dengan segala implikasinya. Kedua, hendaknya dalam persoalan memilih pasangan harus berkesadaran, konsisten, tanggung jawab, terbuka dan dewasa. Hal ini dilandasi dengan pertimbangan-pertimbangan yang mendalam dan nilai-nilai normatif masyarakat secara proporsional. Diyakinkan dengan dua tawaran ini yang namanya problema hidup akan segera teratasi.

\section{Pengaruh Kafa'ah Dalam Perkawinan Terhadap Terciptanya Keharmonisan Rumah Tangga}

Telah disebutkan beberapa faktor yang ditetapkan oleh Fuqoha, faktor-faktor tersebut merupakan syarat yang ideal, sebab sebagai jaminan

${ }^{97}$ Ali Yusuf As-Subki, Figh Keluarga, Jakarta: Amzah, 2010, h. 58. 
kebahagiaan dan kesejahteraan hidup berumah tangga. Pernikahan yang sukses adalah yang dibangun di atas aspek-aspek spiritual, moral dan religius, karena ini lebih stabil dan mampu berdaya tahan daripada aspekaspek material, seperti kekayaan, ketampanan atau kecantikkan, dan jabatan. Seseorang yang memilih pasangan hidupnya hanya dengan mempertimbangkan material semata, pernikahannya lebih terancam kehancuran, dan lebih mudah rapuh daripada seseorang yang memilih pasangan hidupnya dengan mempertimbangkan aspek spiritual..$^{98}$

Wanita yang menikah demi harta, ketampanan, atau jabatan suami, biasanya akan meninggalkan suaminya atau mengalami krisis cinta, jika sang suami jatuh miskin atau kehilangan jabatan. Begitu juga laki-laki yang menikah demi kecantikkan dan kemudaan isterinya, biasanya akan mudah meninggalkan isterinya jika sang isteri sudah tidak cantik dan muda lagi.

Pernikahan yang dibangun di atas pondasi agama dan akhlak, akan lebih kukuh, kuat, dan aman dari ancaman kehancuran, karena kedua hal tersebut sangat kuat dan tidak mudah berubah, dan mampu bertahan menghadapi badai rumah tangga. Sebab, agama adalah penunjuk bagi akal dan hati, pencerah bagi pikiran dan perasaan. Selain itu, keberadaan agama tidak menghalangi keberadaan sifat-sifat lain. Istri yang memiliki keberagamaan yang baik, akan membuat suami merasa tentram. Artinya, suami percaya kepada istri yang mengetahui rahasianya, mendidik anakanaknya, menjaga hartanya, nama baiknya, dan nama baik keluarganya. Inilah kebahagiaan keluarga. Karena itu, jadikanlah agama sebagai prioritas utama dalam memilih pasangan. ${ }^{99}$

Sudah waktunya untuk kembali kepada agama dan ajaran-ajaran Islam, karena kebahagiaan terletak pada upaya menerapkan ajaran Allah SWT. Sebab, tidak tersisa lagi harapan bagi seseorang kecuali dengan mewujudkan keluarga Islami. Kemampuan menciptakan keharmonisan, saling pengertian, dan keserasian sangat penting untuk mewujudkan keturunan yang baik, yang dapat mengeluarkan umat Islam dari kehinaan menuju kemajuan, kekuatan, dan kemuliaan. ${ }^{100}$

${ }_{98}$ Muslich Taman, Aniq Farida, kado Membentuk Rumah Tangga Sakinah Mawaddah Wa Rahmah, Jakarta: Pustaka AL-Kautsar, 2007, h. 31

${ }^{99} \mathrm{Ibid}, \mathrm{h} .32$.

${ }^{100}$ Muslich Taman, Aniq Farida, kado Membentuk Rumah Tangga Sakinah Mawaddah Wa Rahmah, h. 34 
Dalam memilih pasangan hidup seseorang tidak boleh berfikir secara dangkal, dan tidak cukup dengan berfikir secara mendalam, namun hendaknya berfikir secara mustanir (cemerlang). Ketika seseorang melihat wanita yang cantik parasnya lalu menikahinya, maka telah menuruti pikiran dangkalnya. Namun jika setelah melihat kecantikkan parasnya lalu berusaha mencari tahu tentang keluarganya, kekayaan, kebiasaan serta perilakunya, baru mengambil keputusan untuk melanjutkan keinginan menikahinya atau tidak, maka saat itu telah berfikir secara mendalam.

Namun belum dianggap cukup, karena seseorang itu harus memutuskannya dengan berfikir secara mustanir yaitu dengan mengumpulkan informasi tentang keluarganya, kekayaan, pengetahuan dan pendidikan sejak kecil, kebiasaan, karakter, akhlak dan tsaqofah Islamiyahnya yang aktif dalam kegiatan dakwah Islam atau tidak, serta perilaku muamalahnya.

Tuntunan Islam dalam memilih calon isteri atau calon suami yaitu agar menjadikan faktor kebaikan agama sebagai faktor utama, kemudian memutuskan dan menjadikan faktor agama sebagai faktor penentu dan diikuti dengan karakter, kecantikkan, kekayaan, keturunan dan sebagainya. ${ }^{101}$ Dengan kata lain faktor agama sebagai faktor utama sedangkan yang lainnya sebagai penyempurna, karena jarang sekali didapati seorang calon istri dan calon suami memiliki faktor-faktor tersebut secara menyeluruh.

Keagamaan merupakan salah satu pertimbangan yang wajib ditaati dalam pernikahan, sebagian ulama memaknai sebagai peringatan agar tidak mengutamakan selain alasan kebaikan agama. Kelanggengan pernikahan, ketentraman suami istri, kebahagiaan keluarga yang dikehendaki oleh Islam dapat dicapai dengan kebaikan agama, karena agama akan menguatkan pernikahan seiring berlalunya waktu dan usia. Sedangkan alasan yang lain berupa kekayaan, kecantikkan dan keturunan, merupakan faktor yang bersifat temporer dan tidak menjamin kelanggengan rumah tangga, bahkan sering kali justru menyebabkan saling membanggakan dan meninggikan diri masing-masing. ${ }^{102}$ Dalam sisi yang lain memang faktor agama juga merupakan satu-satunya yang menjadi kesepakatan dan titik temu dari pendapat semua mazhab tentang kriteria kafa'ah.

101 Yahya Abdurrahman, Risalah Khitbah, Bogor: Al Azhar Press, 2013, h. 83.

102 Yahya Abdurrahman, Risalah Khitbah, h. 109. 
Penentuan kafa'ah dari segi agama juga bisa dikaitkan dengan tujuan pernikahan. Seseorang yang berfikir atas dorongan Islam dalam mewujudkan dan menginginkan berumah tangga, akan memperhatikan dengan penuh kejelasan dan mendapatkannya tanpa letih terhadap berbagai tugas terpenting dan tujuan keluarga menurut Islam, di antaranya yaitu: (1) untuk mendapatkan kenyamanan jiwa dan ketenangan hidup dengan bersamasama, (2) untuk menjaga kehormatan diri, (3) untuk mendapatkan keturunan, (4) bekerja sama dalam menghadapi kesulitan hidup, (5) melaksanakan hakhak keluarga. ${ }^{103}$

Dalam undang-undang perkawinan (UU No. 1/1974), tujuan perkawinan dalam pasal 1 sebagai rangkaian dari pengertian perkawinan, yakni:

"perkawinan ialah ikatan lahir bathin antara seorang pria dengan seorang wanita sebagai suami isteri, dengan tujuan membentuk keluarga (rumah tangga) yang bahagia dan kekal berdasarkan keTuhanan Yang Maha Esa". ${ }^{104}$

Jika dilihat dari tujuan pernikahan tersebut, kafa'ah dalam perkawinan dapat mendukung tercapainya tujuan pernikahan. Tujuan pernikahan dapat tercapai apabila kerjasama antara suami isteri berjalan dengan baik.

Bahwa setiap manusia, baik laki-laki maupun perempuan yang Allah SWT ciptakan, memiliki tugas masing-masing untuk menjalankan roda kehidupan di muka bumi, dan salah satu ciri kebesaran Allah adalah ketika menyatukan kedua bentuk manusia dalam satu bahtera rumah tangga, sehingga keduanya dapat saling mengisi dan melengkapi.

Laki-laki dan perempuan seperti layaknya siang dan malam, memiliki tugas dan kewajiban yang berbeda dalam menjalankan roda kehidupan. Akan tetapi, dapat juga saling mengisi dan melengkapi dalam menjalankan tugas masing-masing. Seorang laki-laki bertugas untuk bekerja, mencari rezeki di luar rumah, memenuhi kebutuhan istri dan anak-anaknya, serta kebutuhan hidup lainnya. Sedangkan seorang perempuan memiliki tugas dalam menjaga kondisi rumah agar tetap nyaman, melahirkan anak-anak, memberikan rasa damai kepada suami, sehingga dapat menghapus kesedihan dan kesulitan yang sedang dihadapi.

${ }^{103}$ Ali yusuf As-Subki, Fiqih keluarga, Jakarta: Amzah, 2010, h. 24.

104 UU. R.I. No. 1 Tahun 1974, Perkawinan dan Kompilasi Hukum Islam, Bandung: Citra Umbara, 2012, h. 2. 
Pernikahan antara seorang laki-laki dan perempuan memiliki konsekuensi sosial yang sangat besar. Oleh karena itu, sepasang calon suami istri harus meletakkan pondasi yang kukuh dan kuat agar pernikahan yang dibangun akan berhasil dan dapat terus melaju, tidak ada pondasi yang lebih kuat dibanding keimanan. Jadi, agama telah menunjukkan bahwa dalam setiap permasalahan harus mempertimbangkan konsekuensinya sehingga kehidupan rumah tangga akan terus berlangsung sampai akhir hayat. ${ }^{105}$

Islam menetapkan hak-hak bersama suami istri yang harus dijaga, diwujudkan, dan ditunaikan dengan baik oleh masing-masing pihak. Akan tetapi, hak ini tidak bisa terwujud kecuali jika masing-masing menjaga komitmen untuk selalu berjalan pada manhaj Allah dan sunnah Rasul-Nya.

Manhaj yang tengah dijejaki dalam hidup rumah tangga yang menjadi pengendaliannya adalah cinta, jalannya adalah kerjasama, tujuan akhirnya adalah ridha Allah, dan salah satu tujuan utamanya adalah mendidik anak dengan pendidikan Islam, bahkan setiap orang yang hidup dengan pasangannya seperti satu jiwa, satu rasa, satu selera, satu pemahaman, dan satu kasih sayang. Ada juga pasangan yang tidak pernah mengalami perselisihan atau pertikaian karena masing-masing pihak menjaga hudud (batasan) dari Allah dalam menunaikan hak pasangannya, melaksanakan tanggung jawab keluarga, mendidik anak, dan menyempurnakan pekerjaan serta tugas rumah tangga. ${ }^{106}$

Hak wanita seimbang dengan hak laki-laki, terdapat dalam Q.S. AlBaqarah/1: 228, yaitu:

Dan para wanita mempunyai hak yang seimbang dengan kewajibannya menurut cara yang ma'ruf, akan tetapi para suami, mempunyai satu tingkatan kelebihan daripada isterinya, dan Allah Maha perkasa lagi Maha bijaksana.

Ayat di atas menyatakan bahwa hak suami istri saling berbandingan, sesuai dengan prinsip, "setiap hak diikuti dengan kewajiban".

Hak masing-masing terhadap pasangan akan diikuti dengan kewajiban yang harus ditunaikan, dengan pembagian prinsip tersebut dapat menjamin adanya keseimbangan hidup suami isteri dalam berbagai segi. Selanjutnya, dapat mendorong terciptanya ketentraman dalam rumah tangga dan keistiqamahan dalam segala urusannya.

${ }^{105}$ Syaikh Mutawalli As-Sya'rawi, Fiqih Perempuan, Jakarta: Amzah, 2003, h. 174.

106 Syaikh Mahmud Al-Mashri, Perkawinan Idaman, Jakarta: Qisthi Press, 2010, h. 237. 
Adapun hak-hak dan etika bersama suami istri yaitu menjaga amanah dimana pasangan suami istri wajib menjaga amanah dan kepercayaan pasangannya, tidak boleh berkhianat dalam hal sekecil apapun, sebab suami istri seperti dua orang partner yang sama-sama harus menjaga amanat, saling menasehati, saling jujur, dan ikhlas dalam setiap urusan kehidupan khusus dan kehidupan umum. Setelah itu saling mencintai dan menyayangi, masingmasing pihak memberikan sebesar mungkin cinta yang tulus dan kasih sayang yang utuh untuk pasangannya.

Saling mempercayai, kedua belah pihak percaya kepada pasangannya dan tidak boleh meragukan sedikit pun kejujuran, ketulusan, dan pengorbananya, sehingga ikatan suami isteri membuat persaudaraan semakin erat, kuat, dan saling menghargai. ${ }^{107}$

Setiap makhluk hidup pastilah memiliki tujuan, begitu pula dengan cinta. Ada tujuan yang hendak diraih dengan semangat cinta yang dahsyat, ada juga cinta yang hanya menuruti kemauan nafsu belaka untuk mendapatkan kedudukan dan harta, serta ada cinta yang hanya pelarian saja. Semuanya itu akan berakhir pada satu muara yang diinginkan, yaitu kedamaian jiwa. Kedamaian akan lahir dari intensitas kesepahaman untuk mencapai tujuan bersama. Saling bekerja sama dengan mengesampingkan kepentingan personal, ego atau kepentingan diri sendiri hingga tercapai apa yang diharapkan, karena cinta akan bersanding dengan kebahagiaan. ${ }^{108}$

Dalam bekerja sama demi kebaikan dan ketakwaan, yaitu sesungguhnya takwa kepada Allah dan amal shaleh yang harus diwujudkan suami istri, dengan bekerja sama merupakan simpanan terbesar keduanya untuk menjaga anak-anaknya, keduanya juga merupakan jaminan terpercaya untuk masa depan keturunan dan keselamatannya. Serta dapat mendatangkan penjagaan Allah kepada keduanya.

Kerja sama antara suami istri dalam kebaikan dan ketakwaan memiliki pengaruh yang besar bagi keduanya, juga bagi keturunannya pada masa sekarang dan masa yang akan datang. Adapun pengaruhnya pada masa depan di dunia adalah seperti dijelaskan Alquran bahwa keshalehan kedua orangtua bermanfaat bagi anak-anaknya, yang terdapat dalam Q.S. Al-Kahfi: 82, yakni:

107 Syaikh Mahmud Al-Mashri, Perkawinan Idaman, h. 239.

${ }^{108}$ Subhan Hariri, Cinta Adalah Pilihan, Jakarta: Inti medina, 2010, h. 35. 
Adapun dinding rumah adalah kepunyaan dua orang anak yatim di kota itu, dan di bawahnya ada harta benda simpanan bagi mereka berdua, sedang ayahnya adalah seorang yang saleh, maka Tuhanmu menghendaki agar mereka sampai kepada kedewasaannya dan mengeluarkan simpanannya itu, sebagai rahmat dari Tuhanmu, dan bukanlah aku melakukannya itu menurut kemauanku sendiri, demikian itu adalah tujuan perbuatan-perbuatan yang kamu tidak dapat sabar terhadapnya.

Jika satu keturunan tumbuh dalam ketaatan kepada Allah dan pengagungan terhadap agama-Nya, maka akan mudah melaksanakan semua tugas syar'i yang dibebankan kepada mereka saat baligh. ${ }^{109}$ Dan selanjutnya hak bersama suami istri dalam persamaan rasa, suka dan duka bersama, yaitu bekerja sama dalam mewujudkan kebahagiaan, dan menjauhkan kesedihan serta penderitaan sebisa mungkin.

Kasih sayang tidak akan datang secara tiba-tiba, tidak pula yang bersumber dari bawah kaki. Jika tidak berusaha untuk mencapainya atau tidak memenuhi sebab-sebabnya, maka tidak pernah bisa mendapatkannya. Di antara sebab-sebab timbulnya kasih sayang ini karena adanya persamaan perasaan dan fitrah. ${ }^{110}$

Maka dari itu, latar belakang diterapkannya konsep kafa'ah dalam perkawinan bertujuan untuk menghindari terjadinya krisis yang melanda, serta mempunyai pengaruh dalam kehidupan rumah tangga, sehingga tercipta suasana damai, aman, dan sejahtera dalam menjalani bahtera. Memilih calon istri atau calon suami menjadi titik awal yang menentukan kelanggengan pernikahan.

Perkara memilih calon istri atau calon suami tidak boleh dilakukan secara sembarangan, banyak orang yang merasa perlu untuk mengetahui secara mendalam terhadap karakter dan sifat-sifat calon pilihan hidupnya. Tentu saja menghendaki pernikahan didasarkan pada pilihan terbaik, dan pilihan dilakukan sesuai dengan syariat, karena ketika Islam menghendaki kelanggengan pernikahan, Islam tidak membiarkan begitu saja, melainkan menghadirkan serangkaian tuntunan untuk menentukan pilihan yang terbaik.

Tercapainya tujuan pernikahan memang tidak mutlak ditentukan oleh faktor keseimbangan atau kesepadanan semata, tetapi hal tersebut dapat menjadi penunjang yang utama, dan aspek keagamaan serta akhlaklah yang

109 Syaikh Mahmud Al-Mashri, Perkawinan Idaman, h. 241.

110 Syaikh Mahmud Al-Mashri, Perkawinan Idaman, h. 246. 
lebih penting dan harus diutamakan dalam menciptakan rumah tangga yang harmonis dan lebih menjamin keselamatan kehidupan rumah tangga yang dibina.

\section{Penutup}

Kafa'ah dalam perkawinan terhadap keharmonisan rumah tangga dilihat dari beberapa kriteria yang menjadi pertimbangan, seperti agama dan akhlak yang mulia, nasab, fisik, serta kekayaan. Dari hal-hal tersebut para ahli fiqh berselisih pendapat untuk menjadikan kesemuanya sebagai unsur kafa'ah. Oleh karena itu, yang dapat menjadi penunjang utama adalah faktor agama serta akhlak yang mulia, yang akan memperlakukan pasangannya sesuai dengan yang diajarkan oleh Allah SWT sehingga dapat menjamin terciptanya keharmonisan rumah tangga. Sedangkan faktor yang lainnya hanya sebagai pelengkap dalam menjalankan kehidupan rumah tangga.

Pengaruh kafa'ah dalam pernikahan dapat dilihat dari beberapa kriteria dalam memilih pasangan hidup. Apabila dalam memilih pasangan hidup demi harta, fisik atau jabatan, biasanya akan meninggalkan pasangannya atau mengalami krisis cinta, jika pasangannya jatuh miskin atau kehilangan jabatan. Begitu juga menikah demi kecantikan dan kemudaan pasangannya, biasanya akan mudah meninggalkan ketika suami atau istri sudah tidak cantik dan muda lagi. Maka dari itu, pernikahan yang sukses adalah yang dibangun di atas aspek-aspek spiritual, moral dan religius yang akan lebih stabil dan mampu berdaya tahan, dilihat dari tujuan pernikahan yang mendukung terciptanya rumah tangga yang harmonis. Tujuan pernikahan dapat tercapai apabila kerjasama antara suami dan isteri berjalan dengan baik sehingga tercipta suasana damai, aman dan sejahtera.

Tercapainya tujuan pernikahan memang tidak mutlak ditentukan oleh kesepadanan semata, tetapi hal tersebut dapat menjadi penunjang yang utama, apalagi dalam hal agama dan akhlak yang baik. Pernikahan yang tidak memperhatikan prinsip kesepadanan, maka rumah tangganya akan mengalami kesulitan untuk saling beradaptasi, saling melengkapi, saling mencintai, saling menghargai, serta saling pengertian. Oleh karena itu, prinsip kesepadanan dilaksanakan untuk dijadikan patokan dalam membentuk rumah tangga yang harmonis. 


\section{Pustaka Acuan}

Abidin, Slamet dan Aminuddin, Fiqih Munakahat 1, Bandung: CV Pustakasetia, 1999.

Abdurrahman, Yahya, Risalah Khitbah, Bogor: Al-Azhar Press, 2013, Cet. III.

Alhamdani, H.S.A, Risalah Nikah, Jakarta: Pustaka Amani, 1989.

Alquran dan Terjemahan, Jakarta: Jami'atul Qura', 2012.

Anshori, Helmi, Menuju Rumah Tangga Sakinah, Jakarta: Departemen Agama, 2004.

Ar-Rifa'i, Muhammad Nasib, Ringkasan Tafsir Ibnu Katsir, Jilid 4, Jakarta: Gema Insani Press, 2000.

Ash-Shan'ani, Muhammad bin Ismail Al-Amir, Subulus Salam, Jakarta: Darus Sunnah Press, 2011, No.928.

As-Subki, Ali Yusuf, Figh Keluarga, Jakarta: Amzah, 2010.

Asy-Sya'rawi, Syaikh Mutawalli, Fikih Perempuan, Jakarta: Amzah, 2003.

Direktorat Urusan Agama Islam, et al., Etika Berkeluarga Bermasyarakat dan Berpolitik, Jakarta: Lajnah Pentashihan Mushaf Alquran, 2012.

Faifi, Syaikh Sulaiman Ahmad Yahya Al-, Ringkasan Fikih Sunnah Sayyid Sabiq, Jakarta: Pustaka Al-Kautsar, 2013.

Fuad, Muhamad, Fiqih Wanita, Jombang : Lintas Media, 2007.

Hafidz bin Hajar Asqalani Al-, Bulughul Maram, Surabaya: Darrul Ilmu, No. 994.

Hariri, Subhan, Cinta Adalah Pilihan, Jakarta: Inti Medina, 2010.

Hasan, M. Ali, Pedoman Hidup Berumah Tangga dalam Islam, Jakarta: Siraja, 2006.

Helmi, Muhammad Ishar, “Pengadilan Khusus KDRT; Implementasi Gagasan Sistem Peradilan Pidana Terpadu Penanganan Kasus-Kasus Kekerasan Terhadap Perempuan (SPPT-PKKTP)", Jurnal Cita Hukum [Online], Volume 2 Number 2 (1 Desember 2014).

Ibdalsyah, Baiti Jannati, Bogor: Gema Insani, 2014. 
Junus, Mahmud, Hukum Perkawinan dalam Islam, Jakarta: Pustaka Mahmudiah, 1964.

Lestari, Sri, Psikologi Keluarga, Jakarta: Kencana, 2012.

Maggalatung, A Salman. "Hubungan Antara Fakta, Norma, Moral, Dan Doktrin Hukum Dalam Pertimbangan Putusan Hakim" Jurnal Cita Hukum [Online], Volume 2 Number 2 (1 December 2014). doi:10.15408/jch.v1i2.1462

Mahalli, A.Mudjab, Menikahlah, Engkau Menjadi Kaya, Yogyakarta: Mitra Pustaka, 2001.

Mashri, Syaikh Mahmud Al-, Bekal Pernikahan, Jakarta: Qisthi Press, 2010. Perkawinan Idaman, Jakarta: Qisthi Press, 2010

Moeslim, Mulia, Membangun Keluarga Bahagia, Jakarta: Pustaka Sinar Harapan, 2006.

Muhammad Ibnu Shalih bin Hasbullah, Abu, Sejak Memilih, Meminang Hingga Menikah, Bogor: Tim Pustaka Ibnu ‘Umar, 2014.

Mundzir, Imam Al-, Shahih Muslim, Jakarta: Pustaka Amani, 2003.

Muslich, Taman dan Aniq Farida, Kado Membentuk Rumah Tangga Sakinah Mawaddah Wa Rahmah, Jakarta: Pustaka AL-Kautsar, 2007.

Mz, Labib dan Aqis Bil Qisthi, Risalah Fiqh Wanita, Surabaya: Bintang Usaha Jaya, 2005.

Noor, Juliansyah, Metodologi Penelitian, Jakarta: Kencana Prenada Media Group, 2011.

Penyusun Kamus, Tim, Kamus Besar Bahasa Indonesia, Jakarta: Departemen Pendidikan dan Kebudayaan, 1991.

Rahman Ghazaly, Abd., Figh Munakahat, Bogor: Kencana, 2003.

Rohim, Nur. "Kontroversi Pembentukan Perppu No. 1 Tahun 2013 Tentang Mahkamah Konstitusi Dalam Ranah Kegentingan Yang Memaksa" Jurnal Cita Hukum [Online], Volume 2 Number 1 (1 June 2014). doi:10.15408/jch.v1i1.1454

Rasjid, Sulaiman, Figh Islam, Bandung: Sinar Baru Algensindo, 2012. 
Sabiq, Sayyid Fiqih Sunnah 3, Jakarta: Pena Pundi Aksara, 2010. Figh Sunnah 7, Bandung: PT Alma'arif, 1997.

Saebani, Beni Ahmad, Figh Munakahat 2, Bandung: CV Pustaka Setia, 2010.

Shihab, M. Quraish, Tafsir Al-mishbah;Pesan, Kesan dan Keserasian Alquran, Jakarta: Lentera Hati, 2002. Wawasan Alquran, Bandung: Mizan, 1999.

Sari, Nilam, Kiat Mendapatkan Pasagan Hidup Yang Tepat, Yogyakarta: Araska, 2014.

Syarifuddin, Amir, Hukum Perkawinan Islam di Indonesia, Jakarta: Kencana, 2007.

Usman, Husaini dan Purnomo Setiady Akbar, Metodologi Penelitian Sosial, Jakarta: PT Bumi Aksara, 2011.

UU. R.I. No. 1 Tahun 1974, Perkawinan dan Kompilasi Hukum Islam, Bandung: Citra Umbara. 2012.

Yasir, Muhamad, Ya Allah Bahagiakan Keluarga Kami, Jakarta: Pustaka AlKautsar, 2013.

Yunus, Nur Rohim, Restorasi Budaya Hukum Masyarakat Indonesia, Bogor: Jurisprudence Press, 2012. 